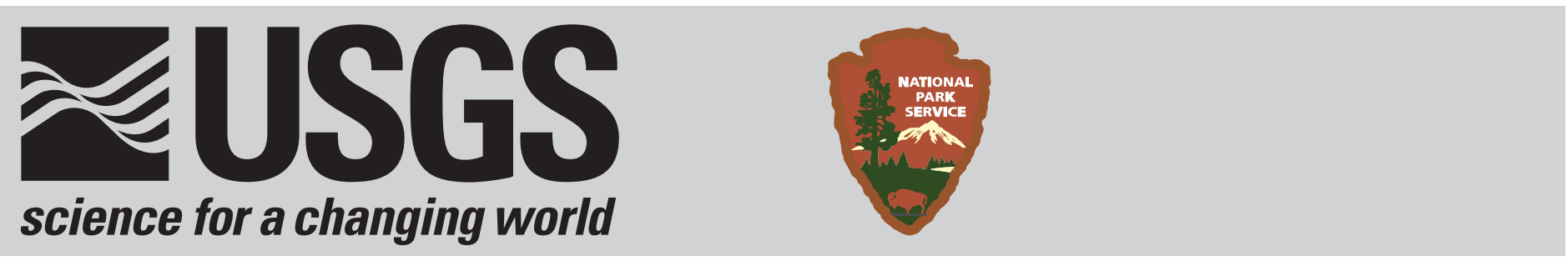

Prepared in cooperation with the National Park Service

\title{
Surficial Geologic Map of the Gates of the Arctic National Park and Preserve, Alaska
}

By Thomas D. Hamilton and Keith A. Labay

Pamphlet to accompany

Scientific Investigations Map 3125

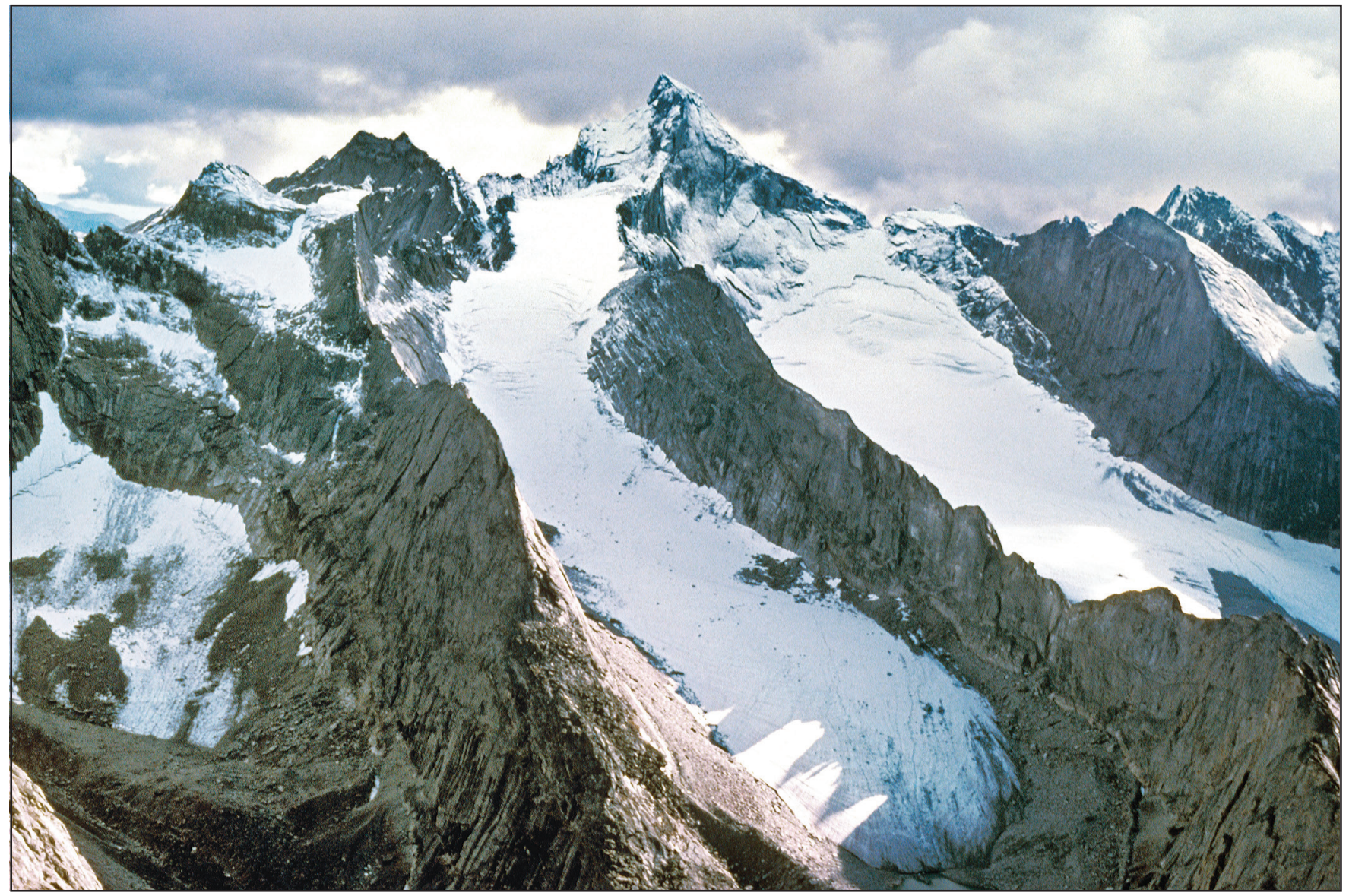

Glaciers and rugged alpine topography of Arrigetch Peaks (Survey Pass quadrangle). Photo by T.D. Hamilton, August 30, 1979 2011

U.S. Department of the Interior

U.S. Geological Survey 
This page intentionally left blank 


\section{Contents}

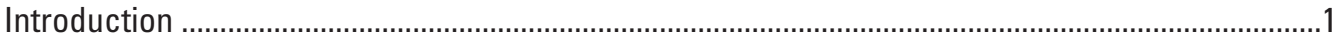

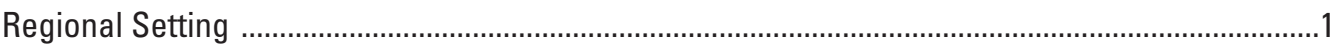

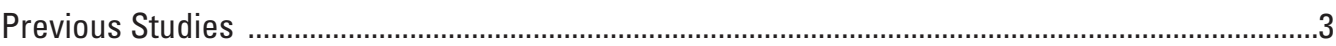

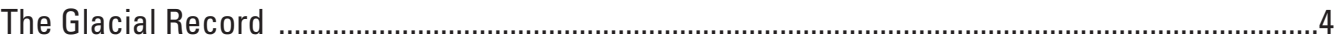

Quaternary Tectonics and Drainage Evolution ............................................................................

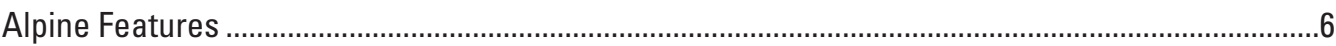

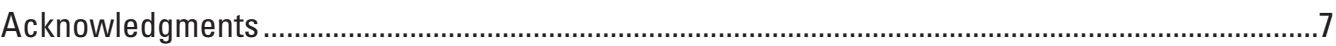

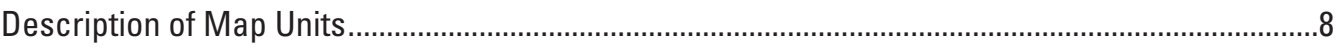

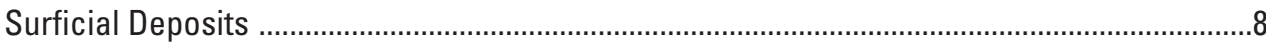

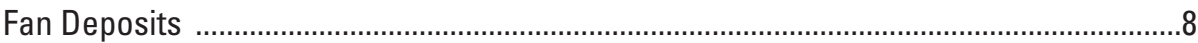

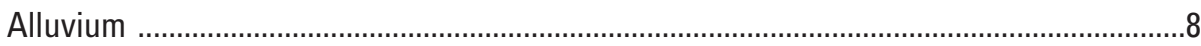

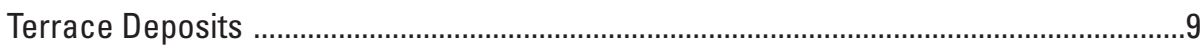

Other Gravel Deposits .................................................................................................

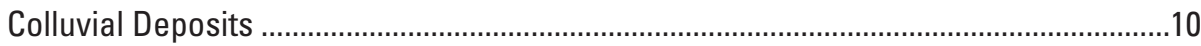

Sand, Silt, and Organic Deposits .................................................................................11

Lacustrine and Glaciolacustrine Deposits ...............................................................12

Glacial Drift and Ice-Contact Gravel ......................................................................13

Late Holocene Glaciation (Neoglaciation) ...........................................................13

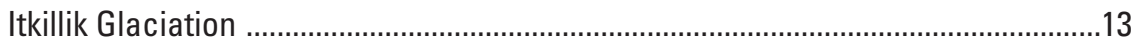

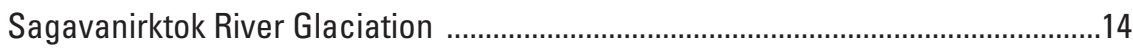

Anaktuvuk River Glaciation .............................................................................

Gunsight Mountain Glacial Interval ...............................................................15

Glacial Outwash and Inwash .............................................................................15

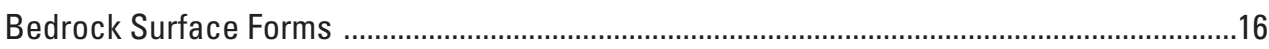

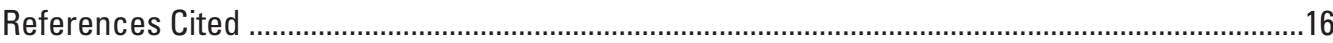

\section{Figures}

Figure 1. Northern Alaska, showing locations of Gates of the Arctic National Park and Preserve, and Noatak National Preserve

Figure 2. Central Brooks Range, showing map area and areas of previously published surficial

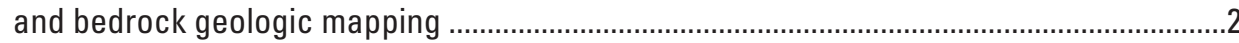

Figure 3. Shaded-relief map of central Brooks Range and adjoining foothills...................................

\section{Tables}

Table 1. Glacial advances in the central Brooks Range (modified from Hamilton, 2009) ..................4

Table 2. Physical characteristics of Pleistocene drifts, central Brooks Range (where differentiated, southern valleys shown in brackets). From Hamilton, 1994 ......................6 
This page intentionally left blank 


\section{Introduction}

The Gates of the Arctic National Park and Preserve (GAAR) is centered over the central Brooks Range of northern Alaska (fig. 1). To the west, it abuts the Noatak National Preserve; its eastern boundary is the transportation corridor occupied by the Dalton Highway and the Alyeska Pipeline. The GAAR extends northward beyond the northern flank of the Brooks Range into the southern Arctic Foothills (Wahrhaftig, 1965). Its southern boundary lies beyond the south flank of the Brooks Range within foothills and depositional basins of interior Alaska. The accompanying surficial geologic map covers all of the GAAR with the addition of a 10-km (6.2-mi) belt or "buffer zone" beyond its boundaries. A narrower $(5-\mathrm{km})$ buffer zone is employed where the GAAR extends farthest north and south of the Brooks Range, in the north-central and southwestern parts of the map area, respectively.

The surfical geologic map incorporates parts of ten surficial geologic maps previously published at 1:250,000 scale (fig. 2). In addition, a small part of the buffer zone mapped in the southwest corner of the map area was compiled from unpublished surficial geologic mapping of the Shungnak 1:250,000-scale quadrangle. Each of those individual maps was developed from
(1) aerial and surface observations of morphology and composition of unconsolidated deposits, (2) tracing the distribution and interrelation of terraces, abandoned meltwater channels, moraines, abandoned lake beds, and other landforms, (3) stratigraphic study of exposures along lake shores and river bluffs, (4) examination of sediments and soil profiles in auger borings and test pits, and exposed in roadcuts and placer workings, and (5) analysis of previously published geologic maps and reports. The map units used for those maps and employed in the present compilation are defined on the basis of their physical character, genesis, and age. Relative and absolute ages of the map units were determined from their geographic locations and from their stratigraphic positions and radiocarbon ages (see reports listed on figure 2 for radiocarbon age data).

\section{Regional Setting}

The central Brooks Range is dominated by rugged, glacierabraded peaks and ridges that rise to $1,800-2,100 \mathrm{~m}(6,000-$ $7,000 \mathrm{ft}$ ) altitude and are indented by deep cirque basins. Broad, glacier-carved troughs extend north and south to both flanks of the range and, in the westernmost part of the map area, trend

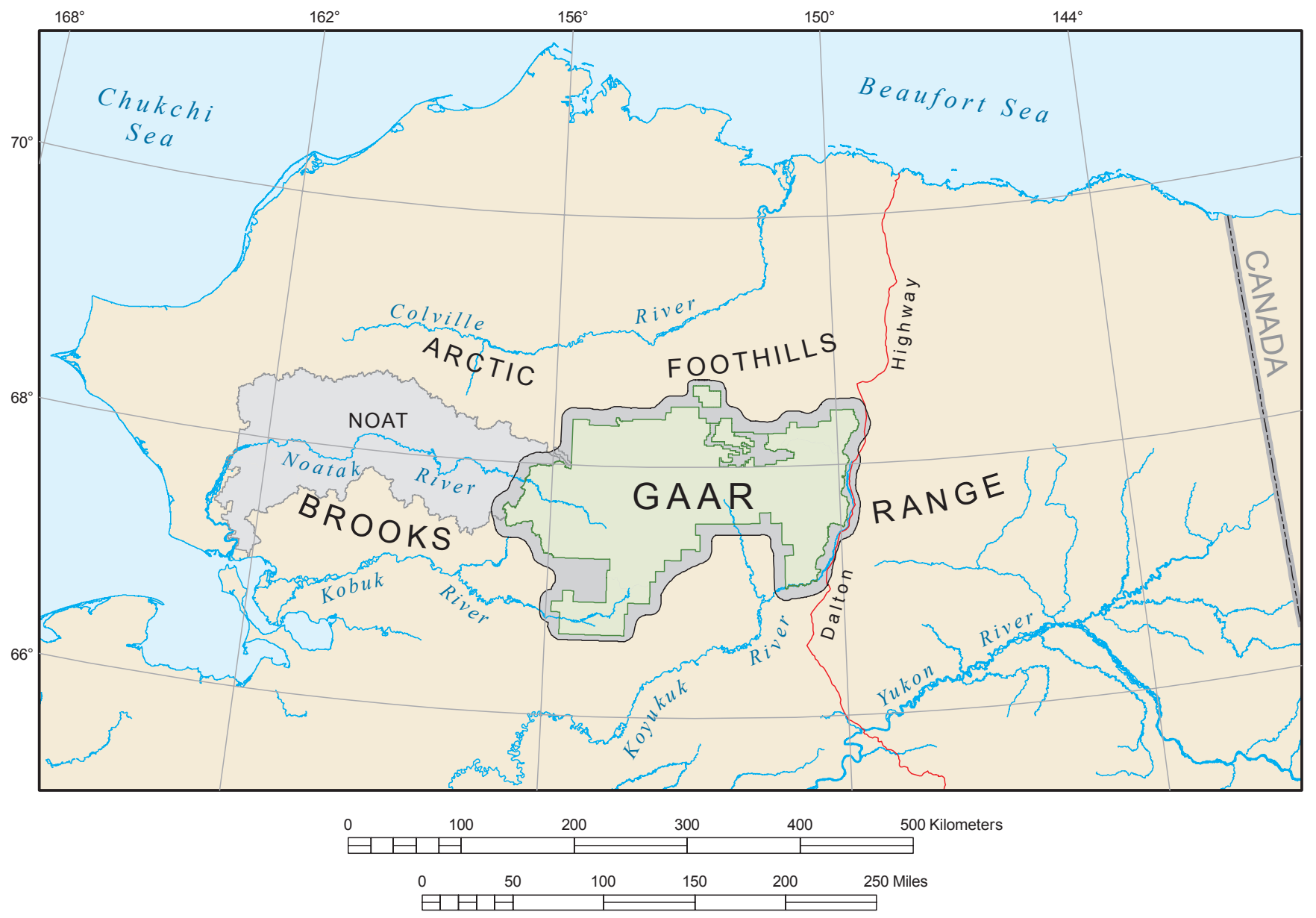

Figure 1. Northern Alaska, showing major drainages and locations of Gates of the Arctic National Park and Preserve (GAAR) and Noatak National Preserve (NOAT). 


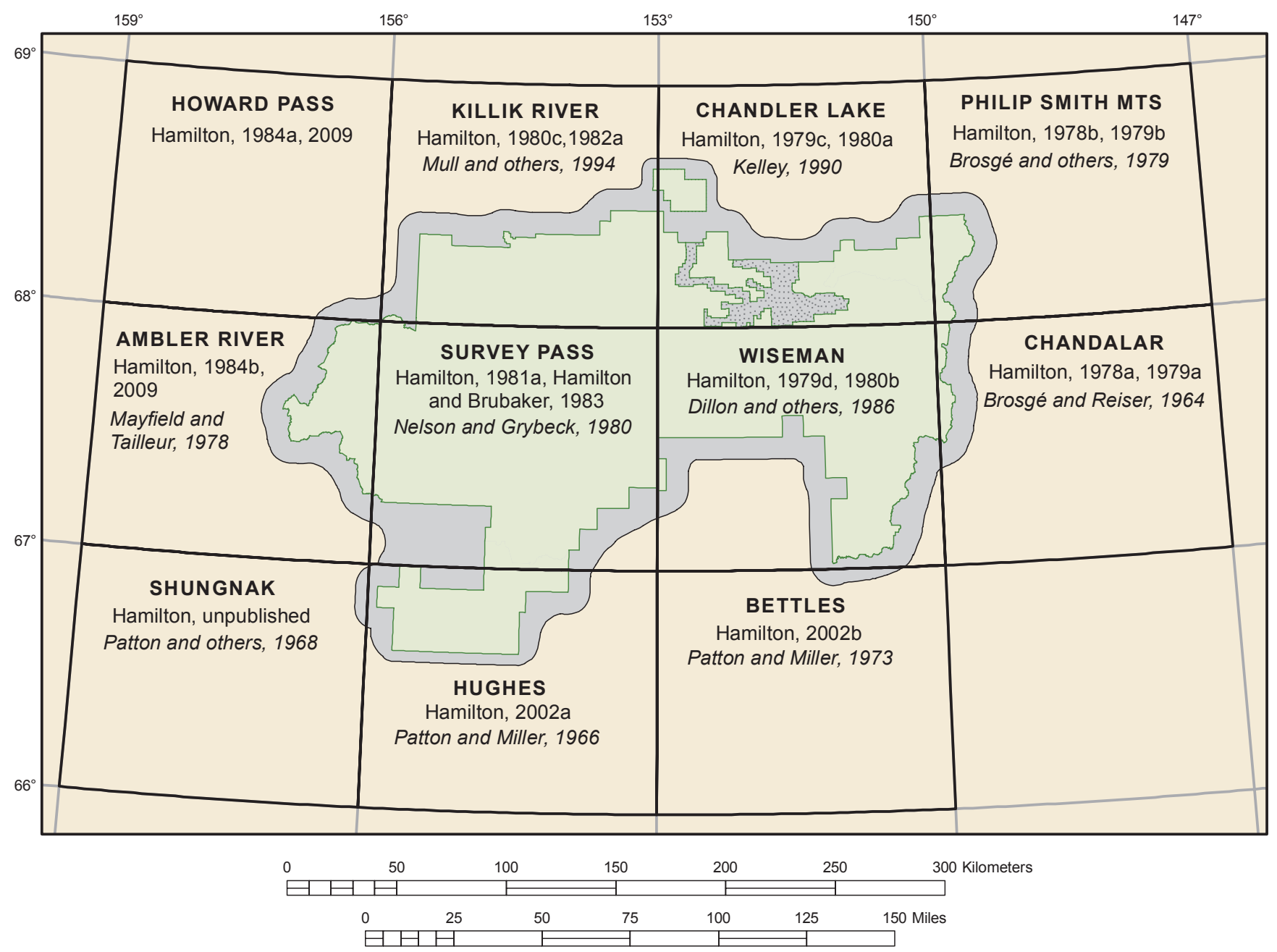

Figure 2. Central Brooks Range, showing Gates of the Arctic National Park and Preserve (in green) and its buffer zone (in gray). Gray stippled pattern designates park inholdings. Area within the buffer zone covers parts of eleven 1:250,000-scale quadrangles. The first reference cited beneath each quadrangle name is the surficial geologic map from which the park map was compiled. The second reference listed for eight of the quadrangles is a compilation of stratigraphic sections and radiocarbon age determinations. Listed in italic is the bedrock geologic map available for ten of the quadrangles.

westward forming the upper Noatak River valley. The eastwest-trending Arctic Foothills (fig. 1) north of the range are dissected by north-flowing drainages and by broad gaps carved by former glaciers. The major valleys followed by those northflowing streams are spaced fairly regularly at intervals of about $100 \mathrm{~km}$ (fig. 3). Terrain beyond the south flank of the Brooks Range is dominated by west-flowing rivers and streams of the Kobuk and Koyukuk drainage systems and by the structural basins that control their courses. Isolated foothills south of the Brooks Range generally rise no higher than $900-1,200 \mathrm{~m}$ $(3,000-4,000 \mathrm{ft})$.

Climate within the map area varies from arctic in the north to subarctic in the south. Winters are long and cold throughout the map area, but summers vary from short and cool in the north to longer and much warmer near and beyond the south flank of the Brooks Range (Shulski and Wendler, 2007, p. 38). Precipitation increases through the summer, reaching maximum values in August (Shulski and Wendler, 2007, p. 62). Both rainfall and snowfall decrease northward and eastward across the map area (Ellis and others, 1981). This gradient is reflected in depth of winter snow cover and in the distribution of modern and Pleistocene glaciers.

Summer temperature gradients are reflected also in the vegetation of the map area. Boreal forest, dominated by birch, spruce, and cottonwood trees, occupies all but the highest hilltops south of the Brooks Range, and extends into the range's southern valleys (fig. 3). Beyond tree limits, tundra vegetation covers all but the higher and steeper rock slopes, ridge crests, and peaks.

Permafrost is present at shallow depth in much of the Brooks Range and throughout the adjoining Arctic Foothills. Depth of its upper surface ranges from 15 to $25 \mathrm{~cm}$ in poorly drained deposits beneath thick moss and sod cover to about half a meter in permeable coarse-grained sediments and several tens of meters beneath the larger lakes and rivers. Permafrost is absent beneath some of the larger water bodies near 


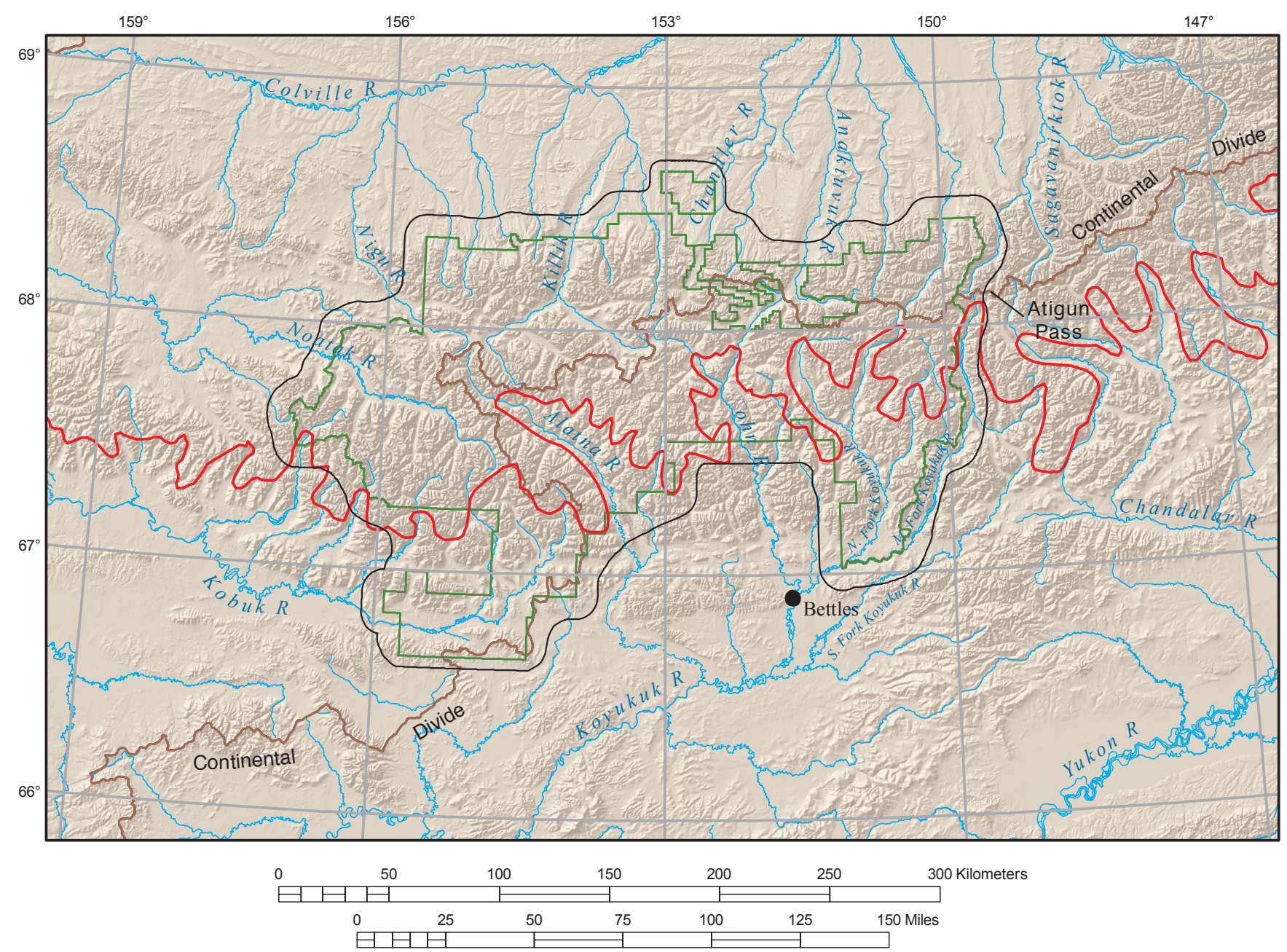

Figure 3. Shaded-relief map of central Brooks Range and adjoining foothills, showing principal drainages, position of arctic treeline (red), and Continental Divide (brown). Boundary of Gates of the Arctic National Park and Preserve is shown in green; black line outlines map area.

the southern flank of the range and in its southern foothills. At those southern localities, depth of its upper surface ranges from 15 to $25 \mathrm{~cm}$ in muskeg areas to $0.5 \mathrm{~m}$ or more in permeable coarse-grained sediments. Although thicknesses generally are unknown, mining, water-well, and other records (Ferrians, 1965; Williams, 1970, p. 31-32; Brown and others, 1997;

Kurtak and others, 2002) suggest that the base of permafrost may lie at depths of 150-300 m through much of the map area, shallowing to $50-150 \mathrm{~m}$ near and beyond the south flank of the Brooks Range.

\section{Previous Studies}

Early accounts of explorations, mining activities, and native settlements in the central Brooks Range are reviewed by W.E. Brown (2007), who provides an extensive bibliography of pertinent publications.

The basic sequence of Brooks Range glaciations was initially determined by Detterman (1953; Detterman and others,
1958), and later modified by Porter (1964), Hamilton and Porter (1975), and Hamilton (1978c, 1979e, 1986). Detailed mapping of surficial geologic units within the range was carried out initially by Porter (1966) in the Anaktuvuk River valley of the Chandler Lake quadrangle and by Hamilton (1969) in the Alatna River valley of the Survey Pass quadrangle. Later reconnaissance mapping along the proposed Trans-Alaska Pipeline corridor was accomplished by U.S. Geological Survey personnel (Ferrians, 1971; Kachadoorian, 1971). Subsequent surficial geologic mapping of the ten 1:250,000-scale quadrangles from which the GAAR map is derived was carried out by U.S. Geological Survey field parties during 1975-1987, with resulting publications shown on figure 2. Surficial geology of the small part of the Shungnak quadrangle at the extreme southwest corner of the map area was mapped from field observations and airphotos, but was not published previously.

Bedrock mapping of the central Brooks Range and neighboring foothills also has been carried out by numerous field parties, as reviewed by Smith and Mertie (1930) and later by Moore and others (1994) and Patton and others (1994). Geologic maps published for each of the 1:250,000-scale quad- 
rangles in the GAAR region are cited on figure 2. A subsequent compilation by Till and others (2008) reviews the largely metamorphic rock units of the south-central Brooks Range and their history of investigations.

Construction of the Trans-Alaska Pipeline and haul road (later renamed the Alyeska Pipeline and the Dalton Highway, respectively) provided unprecedented access to the eastern part of the map area. This has led to a wide range of geologic, hydrologic, and permafrost studies (for example, Brown and Kreig, 1983; Ellis and Calkin, 1979; Ellis and others, 1984; Onesti, 1983; Onesti and Walti, 1983; Sloan and others, 1976; Yoshikawa and others, 2007). The Dalton Highway has also provided a route into the Brooks Range and Alaska's Arctic Slope for permafrost-related field trips (Brown and Kreig, 1983; Walker and others, 2009), and for other field trips and commercial tours (Diel and Banet, 1993).

\section{The Glacial Record}

Pleistocene glaciers originated in cirques along the continental divide that separates north-flowing from south-flowing drainages of the central Brooks Range; and more locally near the north flank of the range, on resistant igneous intrusions south of the divide, and on some of the higher uplands south of the range. Most of those localities remained active centers of snow accumulation and frost action during the Holocene, as attested by concentrations of modern glaciers, active and inactive rock glaciers, cirque moraines, and talus aprons. A small ice cap may have formed on uplands around the heads of the Alatna and Nigu River valleys, where high-altitude erosion surfaces (cross-hatched pattern) are common. These surfaces bear a thin cover of slightly weathered felsenmeer and erratic stones; they evidently were eroded by glaciers during the last glacial maximum (Itkillik II glaciation), and probably also during earlier glaciations as well. Some mountain valleys within the map area lacked high-altitude source areas, and those valleys probably were unglaciated during Itkillik II time but were glaciated earlier. The lower courses of many of those unglaciated valleys were filled with ice from main-valley glaciers, which extended as much as $10 \mathrm{~km}$ into each of them. In addition to thick moraine dams near their mouths, the unglaciated valleys contain inactive alpine fans and thick colluvial aprons that formed under severe periglacial conditions during Itkillik II time.

Although some glaciers radiated from local uplands south of the Brooks Range, most glaciers flowed north and south through deeply incised valley systems to terminate at and beyond both flanks of the range. Outwash trains were deposited along streams that issued from the ice fronts, and lakes formed behind moraine dams and in other localities blocked by glacier ice. Loess derived from outwash, drained lake basins, and other glacial deposits formed thick and extensive blankets across upland surfaces that lay beyond the limits of the younger glacial advances.

Drift of five major glacial intervals (table 1) is recognized within northern valleys and adjoining foothills of the map area. Drift and erratic boulders of the Gunsight Mountain glacial interval represent one or more glaciations of probable late Tertiary age in the Arctic Foothills region (Hamilton, 1979c, 1979e; 1986). Extensive alluvial terraces of Tertiary (?) age (unit Ttg) originate or are truncated at the northern limits of Gunsight Mountain drift and erratic boulders; the terraces may in part be contemporaneous with Gunsight Mountain glacial advances and incorporate Gunsight Mountain outwash. The oldest Pleistocene terraces (unit $\operatorname{tg}_{1}$ ) contain scattered residual boulders derived from Gunsight Mountain drift; these terraces therefore postdate the glacial advances of Gunsight Mountain time. The northern limits of Gunsight Mountain residual boulders incorporated in younger terrace deposits lie beyond the north margin of the map. Probably correlative erratic limits

Table 1. Glacial advances in the central Brooks Range (modified from Hamilton, 2009).

\begin{tabular}{|c|c|c|c|}
\hline Glacial Event & Age Assignment & Age (yr)1 & Reference \\
\hline Neoglaciation & Late Holocene & \multirow{2}{*}{5,000} & \multirow{2}{*}{ Hopkins, 1975} \\
\hline & Early Holocene & & \\
\hline Late Itkillik readvance & & 10,000 & Hopkins, 1975 \\
\hline Itkillik II & $\begin{array}{l}\text { Late Pleistocene } \\
\text { (Itkillik glaciation) }\end{array}$ & 12,800 & Hamilton, 1986 \\
\hline & & \multirow[t]{2}{*}{26,000} & \multirow[t]{2}{*}{ Hamilton, 1986} \\
\hline Itkillik I & & & \\
\hline Sagavanirktok River & Middle Pleistocene & $-122,000$ & Richmond and Fullerton, 1986 \\
\hline Anaktukuk River & Early Pleistocene & 780,000 & Baski and others, 1992 \\
\hline Gunsight Mountain & Late Tertiary & $2,600,000$ & Mascarelli, 2009 \\
\hline
\end{tabular}

${ }^{1}$ Ages to 26,000 yr given in radiocarbon years before present; older ages in calendar years 
were mapped near Anaktuvuk Valley by Detterman and others (1963).

The Anaktuvuk and Sagavanirktok glaciations of Detterman (1953) are currently termed Anaktuvuk River and Sagavanirktok River glaciations to avoid confusion with previously named rock-stratigraphic units (Keroher and others, 1966, p. 91 and 3379). In the Arctic Foothills region, drift sheets of Anaktuvuk River age have been modified by stream erosion, forming dissected surfaces that extend downvalley into alluvial terraces of early Pleistocene age (unit $\operatorname{tg}_{1}$ ). The terraces stand at the same general level as outwash of Anaktuvuk River age; therefore they may in part be contemporaneous with the Anaktuvuk River glaciation. Drift and outwash of Sagavanirktok River age show the same relation to younger Pleistocene terraces in the Arctic Foothills region (unit $\operatorname{tg}_{2}$ ), which are believed to be in part younger and in part contemporaneous with this glacial event. Sagavanirktok River drift locally forms two units that contrast in postglacial modification (Hamilton, 2003; Keller and others, 2007) and possibly were separated by a nonglacial interval. Pediment glacial deposits of probable Sagavanirktok River age at the north flank of the range beyond the map area (crosshatched map pattern in Hamilton, 1980c) have been cut into glacial deposits of probable Sagavanirktok River age. A major erosion interval appears to have separated the Sagavanirktok River glaciation from ice advances of Itkillik age.

Hamilton and Porter (1975) divided the Itkillik glaciation into Itkillik I and II phases (hereafter termed Itkillik I and Itkillik II); its drift is designated $\mathrm{id}_{1}$ and $\mathrm{id}_{2}$, respectively. Porter (1964) had defined four stades of Itkillik glaciation based on type localities within the Anaktuvuk Valley, but restudy of these localities indicates that drifts of his Banded Mountain and Antler Valley stades correspond to the separate Itkillik I and II glacial advances and that deposits of his Anayaknaurak and Anivik Lake Stades do not represent separate glacial readvances (Hamilton, 1979e). Drift of late Itkillik II age (unit id 3 ) represents deposits formed during final events of the waning Itkillik glaciers near their source areas along the Continental Divide (fig. 3) and close to the south flank of the Brooks Range. That drift formerly had been assigned to the Alapah Mountain glaciation (Detterman and others, 1958; Porter, 1964), but was later reinterpreted as alpine moraines that formed during a late readvance of Itkillik II glaciers (Hamilton, 1979c). Unstable kettles with actively caving gravel rims along the north flank of the Brooks Range and within some of its northern valleys suggest that drift of Itkillik II age may still be partly ice cored in those localities (Hamilton, 1982b).

Radiocarbon ages on glacial deposits across the central Brooks Range (Hamilton, 1979a, b; 1980b; 1982a, 1986, 1994; Hamilton and Brubaker, 1983; Hamilton and others, 1987) indicate that the Itkillik I glaciation occurred largely or wholly before $53,000{ }^{14} \mathrm{C}$ years B.P. ${ }^{1}$, and that Itkillik II glacial advances began about 29,000 yr B.P. and culminated about 20,000 years ago. Late Itkillik readvances to positions at or near the north flank of the Brooks Range took place about 12,500 to 11,500 yr B.P. (Hamilton, 1986, 2003). Post-Itkillik basin-filling

${ }^{1}$ All numerical ages given in this section are in radiocarbon years B.P. (before present). had commenced by at least 10,500 yr B.P. in some valleys (Hamilton, 1986, 2009). The Itkillik II glaciation clearly lies within the time range of late Wisconsin glaciation in the standard North American glacial succession. Because of their significant age differences, drifts of Itkillik I and II ages differ in their degrees of postglacial modification by weathering, erosion, and mass wastage. Therefore, the drifts can be differentiated by use of such criteria as moraine morphology, boulder weathering, and soil development (table 2), and they show distinctive differences in soil geochemistry (Munroe and Bockheim, 2001; Keller and others, 2007).

Glacier advances of Itkillik II age were extensive in the eastern and central parts of the map area, but became progressively more restricted westward because of lower lying potential source areas at valley heads. Some mountain valleys near the western part of the map area did not support glaciers of that age. Those valleys differ from their neighbors in containing inactive fans and thick colluvial aprons that presumably formed on ice-free surfaces during Itkillik II time.

The Fan Mountain I and II glacial advances of Porter (1964) are equated with the late Holocene neoglacial interval as described by Porter and Denton (1967) for the North American Cordillera, and Porter and Denton's terminology is followed here. Cirque-glacier activity and correlative episodes of talus formation and rock-glacier motion have been dated provisionally by Calkin and Ellis (1980, 1981), Ellis (1978, 1982), and Ellis and Calkin, 1984) using lichenometry, and by Hamilton (1981b) on the basis of ${ }^{14} \mathrm{C}$-dated episodes of alluviation in cirque-headed stream valleys. Older Neoglacial drift (unit $\mathrm{nd}_{1}$ ) may have formed mainly between about 4,000 and 2,000 yr B.P., with some moraines enclosed within the older drift perhaps as young as 800 years. More recent Neoglacial deposits (unit $\mathrm{nd}_{2}$ ) reflect widespread "Little Ice Age" glacial readvances of the past 450 years. Nearly all moraines of this age occur in cirques occupied by existing glaciers. Neoglacial moraines and other cirque deposits are abundant in eastern and central parts of the map area but become increasingly rare westward as the altitude of valley heads decreases.

About 234 modern cirque glaciers have been identified in the map area. Most glaciers are small in size, having surface areas of $1 \mathrm{~km}^{2}$ or less. Most have undergone rapid retreat during the past century (Hamilton, 1965; Ellis and Calkin, 1979; Ellis and others, 1981), and many present-day glaciers are stagnating and becoming unrecognizable under thick accumulations of ablation debris.

\section{Quaternary Tectonics and Drainage Evolution}

Although the eastern Brooks Range has been tectonically active during the Quaternary (Grantz and others, 1983; Moore and others, 1994), the central part of the range has been largely inactive during that interval. Glacial deposits of the eastern Brooks Range show the impact of severe drainage disruption between successive glacial advances owing to crustal movements. Beyond the north flank of the central Brooks Range, in 
Table 2. Physical characteristics of Pleistocene drifts, central Brooks Range (where differentiated, data from southern valleys shown in brackets). From Hamilton, 1994.

\begin{tabular}{lccccc}
\hline Glaciation & $\begin{array}{c}\text { Width of } \\
\text { moraine } \\
\text { crests }(\mathbf{m})\end{array}$ & $\begin{array}{c}\text { Maximum } \\
\text { flanking } \\
\text { slopes }\left(^{\circ}\right.\end{array}$ & $\begin{array}{c}\text { Boulders per } \\
\mathbf{2 5 0} \mathbf{~ m}^{\mathbf{2}}\end{array}$ & $\begin{array}{c}\text { Maximum } \\
\text { boulder } \\
\text { protusion (cm) }\end{array}$ & $\begin{array}{c}\text { Maximum } \\
\text { depth of } \\
\text { oxidation (m) }\end{array}$ \\
\hline Itkillik II & $3-5$ & $18-23$ & $12-215$ & $40-80$ & 0.3 \\
Itkillik II & {$[2-3]$} & {$[16-22]$} & {$[0-191]$} & {$[20-30]$} & \\
Sagavanirktok & $5-20$ & $15-20$ & $9-213$ & $25-50$ & $1.0-1.2$ \\
River & {$[5-15]$} & {$[14-20]$} & {$[0-135]$} & {$[\leq 20]$} & $>8$ \\
Anaktuvuk & $75-200$ & $2-3.5$ & $1-5$ & 100 & $>30$ \\
River & 500 & 1.2 & $0-1$ & 10 & \\
\hline
\end{tabular}

contrast, glacial deposits of early to late Pleistocene age nest symmetrically within each other; thereby indicating long-term persistence of drainage courses. However, the differences in relative extent of glacial advances between adjoining valleys during that interval record the progressive development of master valleys that are spaced about $100 \mathrm{~km}$ apart as the result of piracies within their upper drainage courses (Hamilton, 2003, p. 4).

Whereas most of the central Brooks Range exhibits little evidence for Quaternary tectonism, a belt of probably active faulting along the south flank of the Brooks Range trends eastward up the Kobuk River valley and continues farther east into the Koyukuk drainage system (Bettles quadrangle). The western part of this belt, termed the Kobuk fault zone, was mapped by Patton and Miller (1966), and has a history of earthquake activity (Gedney and Marshall, 1981). More recent surficial geologic mapping (Hamilton, 1984c, 2002a, b) has demonstrated fault offsets of deposits dating from the middle and late Pleistocene (Sagavanirktok River and Itkillik glaciations). Aligned faultrelated geomorphic features include 1) elliptical pingos and sand extrusions, 2) elongate sag and thaw ponds, 3) fault scarps, 4) uplifted lake shores, 5) offset drainages, and 6) anomalously deep, narrow, and straight gully systems. Those features, forming single and multiple fault strands, could be traced nearly continuously for nearly $40 \mathrm{~km}$ up the floor of the Kobuk River valley (southwest corner of map area) then intermittently for another $120 \mathrm{~km}$ across the Hughes and Bettles quadrangles into the Koyukuk River valley near Bettles (just beyond southern boundary of the map area, fig. 3). Right-lateral offsets evident at some stream crossings are consistent with the dextral offsets indicated by recent seismicity along the fault (Gedney and Marshall, 1981). The Kobuk fault zone may form part of a major regional structure that extends east-west across much of northwest Alaska (Patton and others, 1994; Avé Lallemant and others, 1998).

Near the south flank of the Brooks Range within the Wiseman quadrangle, lineaments (straight linear features) are evident in unconsolidated deposits near the south flank of the Brooks Range and south of the Koyukuk River near the confluence of its North and Middle Forks. These features are expressed as aligned and unusually straight swales, gullies, and vegetation lines, associated in some places with pingos or pingo clusters
(Hamilton and Obi, 1982), stream deflections, or abrupt linear boundaries of surficial map units. No vertical or horizontal offsets of unconsolidated deposits could be detected in the field, however, and a fault origin for these linear elements is unproven. They may represent true faults, perhaps caused by isostatic readjustments at the time of deglaciation (for example, Pelletier, 2004; Hampel and others, 2007); alternatively, they may merely be surface expressions of underlying bedrock structures.

\section{Alpine Features}

In addition to cirques, their glaciers, and associated moraines, other distinctive alpine deposits and landforms are characteristic of the higher parts of the central Brooks Range. Many of these features are related to rapid production of angular rock debris by frost action and other weathering processes on the walls of upper mountain valleys and on other steep slopes oversteepened by erosion of former glaciers. Talus cones and aprons, steep alpine fans, rock glaciers, snow-avalanche tracks, and other alpine features have been studied most intensively (Brown and Kreig, 1983; Walker and others, 2008) near the Dalton Highway in the Atigun Pass area (fig. 3).

Talus (unit tr) consists of angular rock rubble that accumulates where rockfall is common. It forms talus cones at the bases of rugged ravines or chutes and broader aprons along the bases of steep cliffs (Washburn, 1980, p. 231-234). Where active today, talus accumulations stand at steep $\left(30^{\circ}-35^{\circ}\right)$ angles, with unstable unweathered surfaces. Inactive talus rubble is weathered and lichen-encrusted, and may support vegetation cover. In southern valleys of the Brooks Range, inactive talus is commonly relict from late Pleistocene intervals of more severe frost climate.

Steep alpine fans (unit af), as described by Walker and others, 2009, p. 17), “....occur at the bases of chutes that commonly broaden upward into larger source areas. They are composed of coarse angular rubble mixed with variable amounts of finer debris. Their surfaces typically exhibit one or more channels bordered by ridgelike levees of rock rubble. Slope angles $\left(12^{\circ}-25^{\circ}\right)$ are intermediate between those of talus cones and alluvial fans. Although formed commonly by slushflows during 
spring snowmelt period, large increments of debris are added at longer intervals during periods of exceptionally heavy summer rainstorms."

Alluvial fans (unit f) in upper mountain valleys appear much like alluvial fans elsewhere, but their upper surfaces commonly are littered with dispersed angular rock rubble up to boulder size (as illustrated in Walker and others, 2008, figs. 20 and 21). Shredded plant remains may also be evident. These debris are carried across the fan surface by slushflows during the spring snowmelt period (Onesti, 1983, 1989). As detailed by Onesti, the floors of steep gorges tributary to upper valleys fill deeply during winter with snow blown by strong winds from adjoining upper slopes and ridge crests. These thick snow accumulations absorb great amounts of meltwater runoff during the spring snowmelt period, finally becoming water-saturated. Highly erosive slush then flows rapidly down the steep floor of the gorge and out across the adjoining alluvial fan.

Rock glaciers (unit rg) generally are fed by rockfalls, and coarse, blocky, angular talus dominates their outer surfaces. These features move by internal deformation (creep) of interstitial or underlying ice, and are classified as either lobate or tongue-shaped (White, 1976). Tongue-shaped rock glaciers are longer than wide, with maximum lengths as great as $2500 \mathrm{~m}$ (Ellis and Calkin, 1979). They commonly form on the floors of cirques, and may be cored by stagnant glacier ice. Lobate rock glaciers, which typically are broader than long, develop below talus cones along the bases of steep valley walls (White, 1976). Their constituent debris is ice-cemented. Active rock glaciers are recognizable by their steep and unweathered frontal slopes, which meet their upper surfaces at sharp angles. Inactive rock glaciers have weathered and lichen-covered frontal slopes, which rise at more gentle angles and round back more gradually to merge with their upper surfaces.

A distinctive variant of rock glacier found along the walls of southern valleys of the central Brooks Range is here termed debris glaciers (unit dg). These features differ from true rock glaciers in their location, mode of nourishment, composition, and mechanism of movement. Debris glaciers typically originate in shallow drainage basins along the upper walls of southern valleys, where they are fed by solifluction and shallow debris flows rather than by rockfall (Ronald Daanen, University of Alaska Fairbanks, written commun.). Several streams of flowing debris commonly merge into a single elongate lobe that may flow $1 \mathrm{~km}$ or more down the valley side, with some lobes extending into and continuing to move through dense forest. In addition to rock rubble, debris glaciers contain decomposed rock (regolith), blocks of sod, soil, spruce logs and other large wood fragments, and lenses or irregular masses of ground ice. The rock rubble typically consists of tabular slabs of schist, phyllite, siltstone, or shale; these slabs generally dip downslope in orientations that reflect movement by internal sliding. Shear planes visible at the termini of some debris glaciers provide further evidence that internal sliding is likely to be an important component of their movement. The coarse debris occurs in an abundant ice-rich matrix of generally micaceous sand and silt that contains little clay, but small wood fragments, humic soil material, and other organic detritus commonly are present (Daanen, 2009). Measurements by Ronald Daanen (written commun.) show that rates of debris-glacier movement commonly average nearly $1 \mathrm{~cm}$ per day.

Talus cones, steep alpine fans, and alluvial fans form a continuum in which intermediate forms are common between each end member. Talus cones and rock glaciers show similar intergradation, with some talus cones exhibiting incipient rockglacier creep on their distal slopes. Rock glaciers and debris glaciers may intergrade in places, but generally these two end members are distinct.

Although snow avalanches are a severe hazard in many upper valleys of the central Brooks Range (for example, Brown and Kreig, 1983; Walker and others, 2008), they commonly leave little trace after melting and in those cases do not constitute mappable surficial geologic units. However, snow-avalanche tracks and deposits (unit av) are conspicuous on forested valley walls, where the passage of snow avalanches destroys or severely damages tree limbs and trunks and associated avalanche-runout zones are littered with woody debris. Avalanche tracks mapped around the heads of the Kobuk and Noatak River valleys in the Survey Pass quadrangle probably reflect unusually high snowfall around the heads of those valleys, which serve as conduits for moist air masses moving inland from the Bering Sea (Ellis and others, 1981).

\section{Acknowledgments}

My initial studies of glaciation in the central Brooks Range were supported by research grants from the Arctic Institute of North America, the Geological Society of America, and the National Science Foundation. Subsequently, a more comprehensive program of surfical geologic mapping of that region was supported by the Arctic Environmental Studies Program of the U.S. Geological Survey, administered by Oscar J. Ferrians Jr. The National Park Service (NPS) contributed to the final compilation and publication of the last two maps (Bettles and Hughes) in the 1:250,000 surficial geologic map series. The NPS, through the Arctic Network Inventory and Monitoring Program, also funded the compilation of the present map and this report.

Most of the surficial geologic mapping of the map area was carried out during 14 expeditions into the central Brooks Range during 1975-1987. The field assistants, helicopter pilots and mechanics, and cooks that participated in each of those expeditions and the pilots that flew fuel, food, and gear in to us are too numerous to mention, but my thanks go to them all. Of particularly valued assistance over many years were David and Tam Ketscher, owners of Sourdough Outfitters and The Bettles Trading Post, who provided food, lodging, and other assistance in Bettles and also flew most of our resupply flights.

Digital representation of the map was developed by Keith A. Labay, who also assisted with unit designations and GIS databases. The map and report also benefited from thorough reviews by Robert B. Blodgett, Bruce A. Giffen, and Frederic H. Wilson, who pointed out errors, omissions, and ambiguities in a previous draft. Discussions with Ronald Daanen helped to clarify my thinking about the newly named debris glaciers and their differentiation from true rock glaciers. 


\section{DESCRIPTION OF MAP UNITS}

\section{SURFICIAL DEPOSITS}

[Nearly all surficial deposits shown on the map are Quaternary in age. Those of inferred Tertiary age are designated by the prefix $T$.

Map units shown in parentheses, for example, (id), indicate thin and generally discontinuous deposits over near-surface bedrock. Map units shown with slashes, such as al/sa, indicate deposits of the first unit above known or inferred subsurface deposits of the second unit (color represents upper unit). Units of either type are described below only where additional explanation is necessary. Units queried where uncertain.]

\section{FAN DEPOSITS}

af Steep alpine fan deposits (Holocene and late Pleistocene) - Coarse, very poorly sorted, nonstratified to weakly stratified, subangular to subrounded silty sandy gravel at mouths of avalanche chutes and steep canyons. Common in upper mountain valleys. Upper segments generally channeled, with levees of angular to subangular coarse debris. Subject to snow avalanches during winter, slushflows during spring snowmelt, and debris flows during summer. Surface gradients generally $12^{\circ}-25^{\circ}$, intermediate between those of alluvial fans and talus cones

af $_{i} \quad$ Steep alpine fan deposits, inactive (late Pleistocene) - As described in unit af. Generally weathered and covered with sod and vegetation. Commonly are periglacial relics that formed beyond limits of ice advances of last major (Itkillik II) glaciation under climate more rigorous than that of present day

Fan deposits (Holocene and late Pleistocene) — Range from poorly sorted, weakly stratified, subangular, silty, sandy coarse gravel at mouths of steep canyons to moderately sorted and stratified subrounded sandy gravel at mouths of large tributary valleys with relatively gentle gradients. Locally subject to icings (aufeis) during winter

$f_{i} \quad$ Fan deposits, inactive (Holocene and late Pleistocene) - As described in unit $f$. Generally weathered and covered by $0.3-0.5 \mathrm{~m}$ organic silt to stony silt beneath sod and vegetation. Differentiated only on large compound fans

$f_{S} \quad$ Silt fans (Holocene and late Pleistocene) - Unusually fine-grained fan deposits consisting of poorly sorted silt and sandy silt. Present only in valley of Kugukpak Creek (Killik River quadrangle), where associated with widespread solifluction deposits and outcrops of Hunt Fork Shale (as mapped by Brosgé and others, 1979)

$\mathrm{f}_{\mathrm{sa}} \quad$ Sand fans (Holocene and late Pleistocene) - Fan deposits in which sand dominates. Mapped only near northeast corner of Shungnak quadrangle

fd Fan-delta deposits (late Pleistocene) - Compound units that consist of alluvial-fan facies, as described in unit $f$, near valley walls that grade distally into well sorted and generally well stratified sand, silt, and fine gravel of deltaic and lacustrine facies. Commonly associated with present-day or former lakes dammed behind end moraines at or near mouths of mountain valleys

$\mathrm{fd}_{\mathrm{a}} \quad$ Fan-delta deposits, active (late Holocene) - Alluvial fan and delta deposits, as described in unit fd. Mapped only along west side of Galbraith Lake (Philip Smith Mountains quadrangle)

$\mathrm{fd}_{\mathrm{i}} \quad$ Fan-delta deposits, inactive (Holocene and late Pleistocene)-Alluvial fan and delta deposits, as described in unit fd. Form eroded remnants around unit $\mathrm{fd}_{\mathrm{a}}$ along west side of Galbraith Lake (Philip Smith Mountains quadrangle) and in Hughes quadrangle

\section{ALLUVIUM}

al Alluvium, undivided (Holocene and late Pleistocene) - Varies from poorly sorted, moderately well stratified, subangular coarse gravel near heads of mountain valleys to moderately well sorted gravelly sand and sandy fine gravel along slow-flowing stretches of major streams. May contain local beds and lenses of sand and sandy silt. Muddy fine gravel and gravelly mud locally present in some streams south of Brooks Range. Along smaller streams, unit includes fan, floodplain, and low terrace deposits that are too small to be designated separately

$\mathrm{al}_{2}$ Modern alluvium (late Holocene) - Gravel to gravelly mud, as described in unit al. Generally unvegetated and subject to annual flooding. Commonly subject to aufeis formation (Yoshikawa and others, 2007). Differentiated only along principal streams within major valleys 
al 1 Low alluvial-terrace deposits (Holocene) - Gravel to gravelly mud, as described in unit al. Mantled with $0.3-1 \mathrm{~m}$ of silt, sand, turf, and peat, and generally vegetated. Forms terraces generally within 3-4 m of modern stream levels. Differentiated only along principal streams

$\mathrm{al}_{\text {sa }} \quad$ Alluvium, sand facies (Holocene and late Pleistocene)-Moderately sorted to well-sorted, fine to medium sand, parallel bedded to slightly crossbedded, commonly with thin interbeds of sandy peat or organic silty fine sand. Deposited by slow-flowing streams within basins partly dammed by end moraines near mouths of mountain valleys. Upper 1-2 m locally reworked by wind into sand sheets and dunes. Commonly grades downward into lacustrine deposits. Readily dissected by streams, leaving low $(3-5 \mathrm{~m})$ paired terraces

\section{TERRACE DEPOSITS}

$t_{2}$ Terrace deposit, low-level (late Pleistocene) - Compound deposit with terrace-like upper surface. Consists of outwash gravel and silty flood-plain deposits of Itkillik II advance underlain by laminated clay and silt (lacustrine) and sandy fine gravel (deltaic) of Itkillik I age. Mapped only in Hughes quadrangle, where deposit stands $8 \mathrm{~m}$ above Reed River near its mouth

$\mathrm{td}_{1} \quad$ Terrace deposit, high-level (middle Pleistocene) - Compound deposit with alluvial surface 53-60 $\mathrm{m}$ above modern river level. Consists of coarse and fine gravel, strongly oxidized gravel, some sand, silt, and clay; and generally thick (up to $24 \mathrm{~m}$ ) till deposits of Sagavanirktok River age. Capped by silt up to $7 \mathrm{~m}$ thick. Mapped only along Kobuk River in Hughes and Shungnak quadrangles

Terrace gravel, undivided (middle and early Pleistocene; late Tertiary?) — Coarse gravel to sandy fine gravel, commonly consisting of rounded to subrounded pebbles and cobbles in sandy matrix. Forms alluvial terraces of uncertain age or origin

Pleistocene terrace gravels, younger (middle Pleistocene) - Oxidized gravel, as described in unit gr, forming terraces generally $12-15 \mathrm{~m}$ high that are inset with within higher alluvial surfaces. Forms lower terraces or valley floors along some smaller streams that originate north of Brooks Range. Bears thick (4-8 m) cap of ice-rich organic silt in some localities. Composed of undifferentiated nonglacial alluvium plus distal outwash of Sagavanirktok River age. Designated only in Killik River quadrangle

tg2 Pleistocene terrace gravels, older (early Pleistocene) - Oxidized gravel, as described in unit gr, along major drainages north of Brooks Range. Forms terraces 30-45 m above rivers in Killik River quadrangle; 45-65 m above rivers in Chandler Lake quadrangle. Commonly contains residual erratic boulders derived from former deposits of Gunsight Mountain drift. Bears thick (5-10 m) cap of ice-rich silt in most localities, and commonly overlies 10-20 m of bedrock exposed by downcutting. Composed of undifferentiated nonglacial alluvium plus distal outwash of Anaktuvuk River age in Killik River quadrangle; commonly caps erosion surfaces formed within drift sheets of Anaktuvuk River age in Chandler Lake quadrangle. Lies beyond outer moraines of Sagavanirktok River Glaciation and above outwash terraces of Sagavanirktok River age

$\operatorname{tg}_{1} \quad$ Pleistocene terrace gravels, oldest (early Pleistocene; latest Tertiary?) — Oxidized sandy gravel, as described in unit gr. Forms terraces 80 to $110 \mathrm{~m}$ above modern stream levels north of Brooks Range in Chandler Lake quadrangle. Generally caps erosion surfaces that formed within drift limits of Gunsight Mountain glacial interval but lie beyond outer moraines and outwash of Anaktuvuk River Glaciation

Ttg Tertiary terrace gravels (late Tertiary) - Strongly oxidized gravel of Tertiary age, containing rounded stones to large cobble size in sandy matrix, capped by ice-rich silt as thick as $10 \mathrm{~m}$ containing thaw basins. Forms erosion remnants, many terracelike in form, 60-150 m above modern stream levels. Streams in some cases have downcut through gravel and then through 30-50 m of underlying bedrock. Mapped only north of Brooks Range along north margin of map area

\section{OTHER GRAVEL DEPOSITS}

gr Gravel, undifferentiated (middle and early Pleistocene; Late Tertiary?) — Gravel and sandy gravel of diverse origins and composition. Generally applied to isolated, gravelly erosion remnants of uncertain origin and composition

gr $_{f n} \quad$ Fine gravel (middle and early Pleistocene) - Rounded pebbles and small cobbles in matrix of slightly oxidized sand that commonly has high quartz content. Forms terrace-like erosion 
remnants and broader alluvial surfaces about 18-23 m above modern drainage levels in lowlands south of Norutak Hills (Hughes quadrangle). Queried where gravel present but grain size uncertain

Piedmont gravel (middle and early Pleistocene; late Tertiary) - Moderately well sorted, rounded to subrounded pebbles of schist and quartz in abundant matrix of medium to coarse sand containing schist chips, commonly interbedded with medium to coarse sand; generally oxidized yellowish-brown (10YR 4/6) to dark yellowish-brown (10 YR 3/4). Grades laterally into fan deposits consisting of platy pebbles, small cobbles, and some large cobbles of schist and quartz in coarse sand-granule matrix. Forms hummocky erosion remnants in trough between Brooks Range and foothills to the south in Survey Pass and Hughes quadrangles. Commonly overlain by erratic cobbles and boulders of Itkillik I age, but abuts moraines of this age in places and may in part be contemporaneous with them

\section{COLLUVIAL DEPOSITS}

Avalanche tracks and deposits (late Holocene) - Angular unsorted unstratified loose rock rubble, commonly with intermixed woody plant debris. Forms tongues and fans along lower walls of mountain valleys. Associated with tracks and chutes where soil and vegetation are generally absent and that commonly are bordered by zones of battered trees or shrubs from which bark and branches have been partly stripped (Luckman, 1978). Recognized only in deep mountain valleys in southwestern part of map area (Survey Pass, Ambler River, and Hughes quadrangles)

Colluvium, undivided (Holocene and Pleistocene) - Mixed solifluction deposits (unit s) and talus-rubble deposits (unit tr) in sheets and aprons more than about 1-2 m thick. Most extensive on moderate to steep slopes above and beyond limits of ice advances of Itkillik age. Also common on upper slopes below exposed or near-surface bedrock

dg Debris glaciers (Holocene and late Pleistocene) - Tabular rock rubble in abundant ice-rich matrix of generally micaceous sand and silt with wood fragments, humic soil material, and other organic detritus commonly present (Daanen, 2009). Commonly highly elongate, extending down valley walls below forest limits. Subject to slow and perhaps intermittent downslope motion. Common in southern valleys of central Brooks Range, where they are most numerous on phyllite, siltstone, shale and schist bedrock. Also present on limestone with siltstone or phyllite interbeds

fl Flow deposits (Holocene and late Pleistocene) - Very poorly sorted rock debris in abundant muddy matrix. Typically develop below arcuate detachment scars resulting from thaw of ice-rich permafrost. Collapse of those headwalls results in continual input of debris and meltwater into flow mass. Forms distinctive steep-fronted lobes that are subject to slow and continuous movement, especially during summer thaw season. These features have been variously termed tundra earthflows, retrogressive flow-slides, bimodal slope failures, or active-layer detachment slides (Brown and Kreig, 1983; Burn and Lewkowicz, 1990; French, 2007, p. 232-233). Common in Killik River quadrangle angular rubble forming tongues and lobes associated with detachment scars and slide tracks on high, steep walls of mountain valleys. Subject to episodes of rapid downslope motion and long periods of relative stability. Most common in upper mountain valleys that supported active glaciers during late Itkillik II time. Although some recent landslides have been reported (for example, Yeend, 1972), most landslide activity probably took place on oversteepened slopes soon after deglaciation.

Subunit (Is) designates incipient landslides marked by fractures and sagging rock masses on mountain slopes. Recognized only in Ambler River and Survey Pass quadrangles

Protalus rampart deposits (late Holocene) - Unsorted, unstratified, coarse angular rock debris forming arcuate low ridges. Associated with persistent snowbanks in shaded sites, most commonly at bases of cirque headwalls. Subject to rockfalls during spring thaw

Rock-glacier deposits, undifferentiated (Holocene and late Pleistocene) - Very poorly sorted, unstratified, coarse angular rock debris with matrix of silt and fine rubble; Active and inactive components (described separately below) either undetermined or too small to be mapped separately. Fed by talus cones and aprons, which commonly are too small to show on map. Form lobate deposits along bases of valley walls and tongue-shaped deposits within cirques 
Rock-glacier deposits, active (late Holocene) - Coarse angular rock debris, as described in unit rg, but containing abundant interstitial ice. Upper surfaces generally unvegetated, unweathered to moderately weathered; with lichen cover sparse. Frontal slopes barren, steep $\left(35^{\circ}-38^{\circ}\right)$, and highly unstable; they meet upper surfaces at abrupt angle. Tongue-shaped deposits commonly overlie stagnant glacier ice. Subject to slow downslope motion

Rock-glacier deposits, inactive (Holocene and late Pleistocene) - Coarse angular rock debris, as described for unit rg, but generally lacking interstitial ice or underlying stagnant glacier ice. Upper surfaces and frontal slopes weathered, covered by lichens, and commonly partly covered by sod and vegetation. Frontal slopes grade into upper surfaces without abrupt angles sorted, unstratified to weakly stratified, stony silt and organic silt; forms smoothly graded, gently to moderately sloping sheets and aprons more than 1-2 m thick. Platy to elongate stones generally oriented parallel to slope. Forms widespread thick deposits beyond limits of Anaktuvuk River drift. Successively thinner and more locally present on successively younger drift surfaces. Within Brooks Range, unusually thick and abundant deposits overlie shale-rich formations and phyllitic bedrock, and appear to be associated with some fault zones.

Subunit (s) designates thin (less than about $1.5 \mathrm{~m}$ ) but widespread and generally continuous solifluction blankets above near-surface bedrock

Talus rubble (Holocene and late Pleistocene) - Angular, unsorted, unstratified rock debris, forming cones and aprons more than $2 \mathrm{~m}$ thick and generally sloping $30^{\circ}-33^{\circ}$ along lower flanks of mountain valleys and on lower parts of cirque headwalls. Also forms thinner and generally discontinuous sheets over many uplands mapped as bedrock. Active and inactive components (described separately below) either undetermined or too small to be mapped separately.

Active talus rubble (designated by symbol only; see Symbols) is generally unvegetated, unweathered to slightly weathered, with lichen cover sparse to absent. Subject to rockfalls from slopes above, especially during spring thaw

Note: Active talus rubble and associated active rock glaciers in cirques of Arrigetch Peaks (Survey Pass quadrangle) are too numerous to label separately and are shown by a special symbol (see Symbols)

Talus rubble, inactive (Holocene and late Pleistocene) - Angular rock debris, as described in unit tra. Generally weathered and lichen covered, and with partial sod cover at some localities. Thin (less than 1-2 m) blankets of stabilized talus occur on many uplands beyond limits of Itkillik glaciation

\section{SAND, SILT, AND ORGANIC DEPOSITS}

Dune sand (Holocene) - Moderately well sorted medium to fine sand commonly containing shale chips and with thin interbeds of sandy peat; grass rootlets may be abundant. Forms extensive parabolic and longitudinal dunes along Killik River near north flank of Brooks Range. Also present in Survey Pass quadrangle, where it forms series of subparallel ridges as much as $6.5 \mathrm{~m}$ high on Alatna River floodplain south of Takahula Lake

Sand deposits (late Pleistocene) - Moderately sorted silty fine sand to medium sand, horizontally bedded to slightly crossbedded, commonly with thin interbeds of sandy peat or organic silty fine sand. Deposited initially by slow-moving streams within sedimentary basins partly dammed by end moraines near north and south flanks of Brooks Range. Upper 1-10 m locally reworked by wind into sand sheets and dunes. Commonly grades downward into lacustrine deposits (see stippled map pattern). Generally dissected by postglacial streams, forming terraces 5-15 m high that border stream channels and modern floodplains of sandy alluvium (unit alsa).

Composite unit al/sa is distinguished in many glacial valleys of the southern Brooks Range (Survey Pass and Wiseman quadrangles), where fluvial reworking of sand into sandy alluvium is more widespread across narrow valley floors stratified to weakly stratified silt and organic silt containing local lenses of stony to sandy silt. Typically ice-rich. Derived from eolian silt (loess) that was eroded by debris flows, solifluction, gulley-incision, and other slope processes, and then redeposited on lower slopes and 
valley floors. Most deposits presently are stable and vegetated, but some in northern part of map area are subject to present-day solifluction activity. Most common in Hughes quadrangle Organic silt deposits (Holocene and late Pleistocene) - Weakly stratified sandy silt, organic silt, and silty peat, containing abundant ice in form of lenses, wedges, and interstitial grains. Formed largely of loess, with admixed organic and solifluction deposits. Fills thaw basins, valleys of underfit streams, and other poorly drained depressions beyond limits of Anaktuvuk River drift north of Brooks Range in Killik River and Chandler Lake quadrangles. Forms smaller and more localized deposits on younger surfaces farther south, but generally is absent from deposits of Itkillik or younger age. High ice content may be largely due to Holocene ice-wedge growth

Upland silt deposits (Holocene and Pleistocene) - Poorly to moderately sorted generally unstratified silt, organic silt, and slightly clayey, sandy or stony silt on uplands of low to moderate relief beyond oldest drift limits and above highest terrace levels both north and south of Brooks Range. Formed from loess mixed by frost action with local organic matter, rock rubble, and other weathering products. Generally bears tussock cover broken by frost boils at sites north of Brooks Range; bears continuous forest cover at sites south of range. Grades laterally into solifluction deposits on slopes steeper than about 1-2 degrees

Muskeg deposits (Holocene and Pleistocene) - Laminated peat composed of sedges and mosses, with scattered leaves, twigs, and other plant fragments. Occurs beneath Sphagnum and black spruce in poorly drained depressions beyond Itkillik II drift limits at and beyond south flank of Brooks Range. Most extensive across basins formerly occupied by lakes of Pleistocene age. Grades laterally into retransported silt deposits near bases of solifluction slopes. Generally contains abundant ice as lenses, wedges, and interstitial grains

\section{LACUSTRINE AND GLACIOLACUSTRINE DEPOSITS}

Beach deposits (Holocene)-Moderately well sorted, coarse to medium sand containing schist chips, interbedded with platy fine gravel; ranges to poorly sorted, gravely sand and sandy fine gravel where mixed by ice shove during spring breakup period. Mapped within Survey Pass quadrangle around Iniakuk Lake and at south end of Walker Lake, where series of raised beach ridges rise to heights of 12-16 m and 18-24 m, respectively. Also mapped around shores of lakes or former lakes in Bettles, Chandler Lake, Hughes, and Philip Smith Mountains quadrangles

Deltaic deposits (Holocene and late Pleistocene) - Generally well stratified sand and sandy fine gravel deposited by streams at lake margins. Commonly build outward into lake, and overlie fine-grained lacustrine deposits. Large deltas currently are forming at north ends of Narvak Lake and Lake Minakokosa near north margin of Hughes quadrangle. Other deltas in map area are too small or too intermixed with other deposits to designate individually

Deltaic deposits, inactive (Holocene) - Composition uncertain. Mapped upstream from active delta at north end of Lake Minakokosa in Hughes quadrangle. May be compound deposit related to multiple lake stages

Lacustrine deposits (Holocene and late Pleistocene) - Well stratified clay, silt, and silty fine sand, grading into sand and gravelly sand near former shorelines and sandy fine gravel near former stream mouths. Include beach deposits too small to be designated separately

Glacial-lake deposits of Itkillik age (late Pleistocene) - As described in unit I, with dispersed dropstones commonly present. Extensive thick deposits occur behind Itkillik-age moraines along floors of most major valleys of central Brooks Range. Shown only by stippled pattern where buried beneath younger alluvium, sand sheets, or solifluction and fan deposits

igl 3 Glacial-lake deposits of late Itkillik II readvance (late Pleistocene) - As described in units I and igl. Associated with moraine dams or drift deposited during late Itkilllik II time

igl2 Glacial-lake deposits of Itkillik II age (late Pleistocene)-As described in units I and igl. Associated with moraine dams or drift deposits of Itkillik II age

igl 1 Glacial-lake deposits of Itkillik I age (late Pleistocene) - As described in units I and igl. Associated with moraine dams or drift deposited during Itkillik I time. Most common in lower mountain valleys of Wiseman quadrangle

Deltaic deposits of Itkillik age (late Pleistocene) — As described in unit dt. Associated with glacial lakes of Itkillik age in Hughes quadrangle

sgl Glacial-lake deposits of Sagavanirktok River age (middle Pleistocene)—As described in units I and igl, generally with silt and (or) muskeg cover up to several meters thick. Mapped only in Hughes quadrangle 


\title{
GLACIAL DRIFT AND ICE-CONTACT GRAVEL
}

\author{
Late Holocene Glaciation (Neoglaciation)
}

nd

Drift of neoglacial age (late Holocene) - Unsorted unstratified coarse to fine angular rubble; forms lobes and arcuate ridges with moderate to steep frontal slopes. Clasts unweathered to slightly weathered; generally unvegetated except by lichens. Generaly restricted to cirques at higher altitudes, commonly near valley heads. Designates drift remnants of uncertain neoglacial age or composite drift bodies too small for subdivision

Drift of late neoglacial age (late Holocene) - Angular rubble, as described in unit nd; forms lobes and arcuate ridges of ice-cored drift with steep, unstable frontal slopes. Unvegetated, unweathered to slightly weathered, and with lichens sparse to absent. Restricted to cirques, and generally associated with active glaciers

Drift of early neoglacial age (late Holocene) - Angular rubble, as described in unit nd. Forms more subdued lobes and ridges with stable frontal slopes; generally eroded by axial streams. Generally in cirques, but locally may extend into upper valleys. Weathered and lichen encrusted, with partial sod cover in some localities. Ice cores generally absent

\section{Itkillik Glaciation}

Drift of Itkillik age, undifferentiated (late Pleistocene) - Unsorted to poorly sorted generally nonstratified compact till, ranging in composition from muddy sandy boulder gravel to clayey stony silt, with local stratified ice-contact deposits consisting of moderately sorted sand and sandy gravel. Contains faceted and striated stones up to boulder size. Designates thick (greater than $3 \mathrm{~m}$ ) drift deposits, usually within mountain valleys, that cannot be assigned to a specific Itkillik moraine system

Drift of late Itkillik II readvance (late Pleistocene) — Till and stratified ice-contact deposits, as described in unit id. Forms sharp-crested end moraines, irregular ground moraine, and steep-sided ice-contact stratified drift deposits in many upper mountain valleys of southern Brooks Range. Forms usually subdued moraines of silty till (probable redeposited lacustrine sediments) near mouths of large mountain valleys along north flank of Brooks Range. Loess cover generally absent, and exposed stones very slightly weathered; oxide penetration to only $20-30 \mathrm{~cm}$ depth in most permeable deposits

Drift of Itkillik II age (late Pleistocene) - Till and stratified ice-contact deposits, as described in unit id, with ice-contact deposits very abundant in most valleys. Forms prominent end moraines and associated glacial deposits north of Brooks Range in major valleys, along both range flanks in other valleys, and in upper Noatak River valley (Ambler River quadrangle). Drift lobes sharply defined, with narrow (generally $1-3 \mathrm{~m}$ ) morainal ridges, prominent knob and kettle morphology, and conspicuously channeled outwash trains. Crests and upper slopes lack loess and solifluction cover, and exposed boulders and cobbles exhibit slight to moderate weathering; oxidation has penetrated 30-50 cm into better drained deposits. Most swales lack solifluction deposits, and abandoned meltwater channels commonly are floored with lichen-covered coarse gravel. Unstable kettles with actively caving gravel rims beyond north flank of Brooks Range indicate that residual glacier ice may persist locally

Drift of Itkillik I age (late Pleistocene) - Till and stratified ice-contact deposits, as described in unit id. In northern valleys, forms closely nested concentric end moraines with flanking slopes up to $20^{\circ}$ and subdued knob and kettle topography; associated with outwash trains partly obscured by solifluction. Moraine crests generally $3-10 \mathrm{~m}$ wide and partly bare of loess; upper slopes are blanketed by 0.5 to $2 \mathrm{~m}$ of stony organic silt (loess and colluvium). Cobbles and boulders exposed at surface are moderately to heavily weathered; stones in soil profiles are etched, pitted, and oxidized to depth of about $1 \mathrm{~m}$. Swales partly filled with 1-3 $\mathrm{m}$ of ice-rich organic silty solifluction deposits. Shallow earthflows common on steep slopes. At and beyond south flank of Brooks Range, forms broad, heavily forested piedmont lobes with large kettle lakes and extensive outwash terraces. Eroded arcuate end moraines and lateral embankments extend from glaciated main valleys of southern Brooks Range into lower courses of unglaciated tributaries.

Subunit $\mathrm{id}_{1 \mathrm{~A}}$ designates outer moraine belt in drift sheets where conspicuous inner moraines 
(designated $\left.\mathrm{id}_{1 \mathrm{~B}}\right)$ represent local readvances of Itkillik I glaciers during interval of general ice wastage.

Subunit $\left(\mathrm{id}_{1}\right)$ designates thin deposits of Itkillik I drift above bedrock. On hillslopes or lower valley walls, these deposits commonly are mixed with silt, rock rubble, and organic detritus, and hence become a compound (glacial-colluvial) unit

ik Kame and kame-terrace deposits (late Pleistocene)-Unusually extensive and thick (generally greater than $30 \mathrm{~m}$ ) deposits of moderately well to well sorted sand, gravelly sand, and sandy gravel within undifferentiated drift of Itkillik age. Forms generally steep-sided knobs or knob complexes on drift sheets of Itkillik age and sharply defined terraces along their margins

$\mathrm{ik}_{3} \quad$ Kame and kame-terrace deposits (late Pleistocene)-Unusually extensive and thick deposits of sand and sandy gravel, as described in unit ik, usually with less than $0.2 \mathrm{~m}$ cover of silt, organic silt, and sod. Formed within and marginal to drift of late Itkillik II readvance

$i_{2} \quad$ Kame and kame-terrace deposits (late Pleistocene)-Thick and extensive gravel deposits, as described in unit ik, within and marginal to drift of Itkillik II age

$\mathrm{ik}_{1} \quad$ Kame and kame-terrace deposits (late Pleistocene)-Unusually thick and extensive sand and gravel deposits, as described in unit ik, within and marginal to drift of Itkillik I age. Occurrence within outwash train associated with Itkillik I glacial advance west of Anaktuvuk River (Chandler Lake quadrangle) suggests persistence of residual glacier ice from Sagavanirktok River glaciation at time of Itkillik I glacial advance

Meltwater deposits (late Pleistocene)_Extensive complexes of kames, kame terraces, and eskers consisting generally of sandy gravel that formed in contact with stagnating glacier ice of late Itkillik II age on floor of Anaktuvuk River valley south of range front and on adjoining valley floor of John River (Chandler Lake and Wiseman quadrangles)

\section{Sagavanirktok River Glaciation}

Sagavanirktok River drift, undifferentiated (middle Pleistocene)—Poorly sorted nonstratified till ranging in composition from silty sandy boulder gravel to clayey stony silt, with local deposits of moderately well sorted ice-contact gravel; generally oxidized and strongly jointed. Erratic boulders sparse; they commonly protrude less than $0.15 \mathrm{~m}$ above ground surface. Forms distinct but subdued end moraines and ground moraine with most crests and flanks covered by continuous blanket of organic silt (loess and solifluction deposits). In northern valleys, surface boulders are composed only of a highly indurated quartzite and conglomerate of Kanayut Conglomerate (Nilsen and Moore, 1984; Moore and others, 1989). Swales and kettles generally contain more than $5 \mathrm{~m}$ of ice-rich organic silt (colluvial and lacustrine deposits). Some ridge crests locally lack silt cover, exposing weathered subrounded gravel of resistant lithologies. Broadly dissected (to 2-3 km width) along major rivers, with depth of erosion 25-40 m.

At and beyond south flank of Brooks Range, forms broad morainal ridges and hummocky till plains; isolated drift remnants occur beyond Itkillik drift limits elsewhere within southern mountain valleys. Generally covered by thick (more than $3 \mathrm{~m}$ ), nonstratified to weakly stratified blanket of silt, stony silt, and organic silt (loess, solifluction, and muskeg deposits). Crests of some ridges and knolls yield limited exposures of weathered gravel consisting of subrounded pebbles, cobbles, and small boulders of resistant lithologies.

Subunit (sd) designates thin (less than 3 to $5 \mathrm{~m}$ ) and generally discontinuous drift deposits on bedrock beyond Itkillik ice limits

$\mathrm{sd}_{2} \quad$ Drift of younger Sagavanirktok River age (middle Pleistocene)-Till and ice-contact gravel, as described in unit sd. Forms subdued end moraine and ground moraine with many ridge crests bare of loess and solifluction cover. Swales and kettles more abundant and less modified than on older deposits of Sagavanirktok River age

$\mathrm{sd}_{1} \quad$ Drift of older Sagavanirktok River age (middle Pleistocene)—Poorly exposed glacial deposits of composition probably similar to unit sd, forming distinct but very subdued and dissected moraines beyond limits of $s_{2}$ drift. Ridge crests and flanks bear generally continuous cover of organic silt

\section{Anaktuvuk River Glaciation}

Drift of Anaktuvuk River age (early Pleistocene)-Bouldery glacial deposits of uncertain composition overlain by continuous cover of organic silt (loess and solifluction deposits) generally more than 2-3 m thick. Erratic boulders very sparse (generally $<1$ per $\mathrm{km}^{2}$ ); they 
typically protrude less than $0.2 \mathrm{~m}$ above ground surface and consist of only most resistant (thick-bedded and nonferruginous) facies of Kanayut Conglomerate. Forms subdued till plains and low broad morainal ridges with gentle $\left(1^{\circ}-2^{\circ}\right)$ flanking slopes except where steepened by postglacial erosion. Former swales and kettles generally filled with ice-rich, silty, organic colluvial and lacustrine deposits more than $5 \mathrm{~m}$ thick. Deeply and broadly dissected by minor as well as major steams, with depth of dissection 45-60 m along most major valleys and to width of $6 \mathrm{~km}$ and depth of $100 \mathrm{~m}$ in Killik River valley. In smaller valleys, widths and depths of dissection are typically about $1 \mathrm{~km}$ and 40-60 m, respectively. North of Brooks Range, occurs beyond drift limits of Sagavanirktok River age and forms oldest and northernmost continuous drift sheets. South of Brooks Range, forms patchy drift remnants south of Kobuk River valley

\section{Gunsight Mountain Glacial Interval}

Tgmd Drift of Gunsight Mountain age (late Tertiary) - Highly eroded bouldery glacial deposits of unknown initial composition, lacking primary relief and overlain by continuous cover of organic silt generally more than 2-3 m thick. Mapped only north of Brooks Range beyond limits of Anaktuvuk River drift. In Killik River quadrangle, former distribution commonly is marked by northern limits of erratic boulders incorporated in terrace deposits of early Pleistocene $\left(\operatorname{tg}_{1}\right)$ age. Recognized in Chandler Lake quadrangle near Nanushuk River and near Gunsight Mountain (north of map margin), where it is associated with abundant erratics of resistant Kanayut Conglomerate facies on postglacial erosion surfaces and with rock-cut channels and benches probably eroded by glacial meltwater streams. Deeply and broadly dissected, with depth of erosion 60-80 m along most valleys. Probably eroded to depth of about $100 \mathrm{~m}$ along Killik River and to about $300 \mathrm{~m}$ along range front east of Kurupa Lake (Killik River quadrangle)

\section{GLACIAL OUTWASH AND INWASH}

Outwash of neoglacial age (late Holocene) - Moderately well sorted and stratified sandy coarse gravel forming modern floodplains and low $(1-3 \mathrm{~m})$ vegetated terraces that extend downvalley from modern glaciers and from end moraines of neoglacial age. Forms mappable unit only in some higher valley heads of Killik River and Survey Pass quadrangles; too small to be designated separately elsewhere

Itkillik outwash, undifferentiated (late Pleistocene) - Moderately well sorted and stratified sandy gravel forming aprons and valley trains in front of moraines of Itkillik age that extend into terrace remnants farther downvalley. Largest stones decrease in size from subrounded cobbles and very small boulders near moraine fronts to rounded to subrounded pebbles and granules farther downvalley

io3 Outwash of late Itkillik II readvance (late Pleistocene) - Sandy gravel, as described in unit io, generally without loess or peat cover and oxidized to only 20-30 cm depth. Forms valley trains beyond end moraines of late Itkillik II age. Terraces near moraine fronts commonly 12-15 m high; they generally are continuous downvalley and merge distally with outwash terraces of Itkillik II age

io2 Outwash of Itkillik II age (late Pleistocene) - Sandy gravel, as described in unit io, generally with thin $(0.3 \mathrm{~m}$ or less) cover of silt and sod. Exposures in northern valleys show stones etched, fractured, and pitted to $30-40 \mathrm{~cm}$ below surface; oxidized to depths of $30-45 \mathrm{~cm}$. Depths are slightly greater in southern valleys $(30-50 \mathrm{~cm}$ and $40-50 \mathrm{~cm}$, respectively). Forms extensive aprons and valley trains in front of Itkillik II moraines. Terraces near moraine fronts are up to $40 \mathrm{~m}$ high in major valleys; they generally are continuous downvalley, decreasing progressively in height to about $3-5 \mathrm{~m}$.

Subunits i02A and io2B designate outwash trains associated with outer and inner moraines west of Kobuk River at south end of Walker Lake (Survey Pass quadrangle). Subunit io2B is lower than io $_{2} \mathrm{~A}$, and is inset within it

io1 Outwash of Itkillik I age (late Pleistocene) - Sandy gravel, as described in unit io, generally with thin to moderate $(0.3-3 \mathrm{~m})$ loess and solifluction cover that contains frost-churned stones with vertical orientations. In northern valleys, upper 1-1.5 m oxidized, with silt illuviation and weathered stones. In valleys at and beyond south flank of Brooks Range, cover of silt and organic silt (loess and solifluction deposits) may be up to $4 \mathrm{~m}$ thick. Forms aprons and valley trains in front of Itkillik I moraines. Terraces are up to $40 \mathrm{~m}$ high near moraine 
fronts, and decrease in height progressively downvalley. Commonly incised within drift of Sagavanirktok River age and dissected in turn by Itkillik II outwash.

Subunits io $1 \mathrm{~A}$ and io $_{1 \mathrm{~B}}$ designate outwash associated with outer and inner moraines of Itkillik I age (units id $\mathrm{i}_{1 \mathrm{~A}}$ and $\mathrm{id}_{1 \mathrm{~B}}$ ) at several localities beyond south flank of Brooks Range

Sagavanirktok River outwash, undifferentiated (middle Pleistocene)—Moderately well sorted and stratified oxidized sandy gravel, with largest stones generally decreasing in size from cobbles and small boulders near moraine fronts to pebbles and cobbles further downvalley. Generally overlain by 1-4 m of organic silt (loess and solifluction deposits). Commonly associated with underfit or abandoned stream courses and dissected to depths as great as $30-40 \mathrm{~m}$ in some valleys

Younger outwash of Sagavanirktok River age (middle Pleistocene) - Sandy gravel, as described for unit so, forming outwash trains originating at outer limits of younger moraines of Sagavanirktok River age or formed within outer moraines of that age

Older outwash of Sagavanirktok River age (middle Pleistocene) - Sandy gravel, as described for unit so, forming outwash trains originating at or near outer limits of older moraines of Sagavanirktok River age

Outwash of Anaktuvuk River age (early Pleistocene) — Oxidized gravel of uncertain composition forming terrace remnants 50-60 m high that originate at outer limits of drift lobes of Anaktuvuk River age. Generally overlain by $3-5 \mathrm{~m}$ of organic silt (frost-churned loess and solifluction deposits). Mapped north of range front in Killik River and Chandler Lake quadrangles

Inwash of Itkillik age (late Pleistocene) - Well sorted to moderately sorted and stratified gravelly sand and sandy fine gravel, commonly grading upvalley into fan deposits and downvalley into lacustrine beds. Loess, sod, and silt cover generally thin (less than $0.2 \mathrm{~m}$ ) to absent. Deposited near mouths of nonglaciated tributaries blocked by Itkillik-age glaciers in main valleys, forming benches and terraces that abut outer flanks of lateral moraines or outer faces of end moraines

Inwash of late Itkillik II readvance (late Pleistocene) - As described in unit ii. Forms deposits that abut drift deposited during late Itkillik II time

Inwash of Itkillik II age (late Pleistocene) - As described in unit ii. Forms deposits that abut drift of Itkillik II age

Inwash of Itkillik I age (late Pleistocene) — As described in unit ii. Forms deposits that abut drift of Itkillik I age

\section{BEDROCK SURFACE FORMS}

Bedrock, undifferentiated - Generally unweathered within Brooks Range, where glacial erosion has created steep valley walls, sharp-crested ridges, and deep cirques. More weathered and subdued in appearance in northern and southern foothills, where it generally is covered by thin sheets of windblown silt (loess) and frost-shattered rock rubble. Lithologies as described by Moore and others, 1994, and Till and others, 2008

Bedrock, glacier-scoured-Bedrock smoothed and abraded by overriding glacier ice. Rock surfaces generally well exposed, streamlined in direction of glacier flow (shown by arrows), and channeled by meltwater. Erratic boulders and cobbles commonly dispersed across rock surfaces

Bedrock, silt-covered-Bedrock with cover of airborne silt (loess), $0.5 \mathrm{~m}$ or more thick over all but the highest and steepest slopes. Common beyond limits of late Pleistocene glaciation in foothills north and south of Brooks Range

\section{References Cited}

Avé Lallemant, H.G., Gottschalk, R.R., Sisson, V.B., and Oldow, J.S., 1998, Structural analysis of the Kobuk fault zone, north-central Alaska, in Oldow, J.S., and Avé Lallemant, H.G., eds., Architecture of the central Brooks Range fold and thrust belt, arctic Alaska: Geological Society of America Special Paper 324, p. 261-268.
Baksi, A.K., Hsu, V., McWilliams, M.O., and Farrar, E., 1992, ${ }^{40} \mathrm{Ar} /{ }^{39} \mathrm{Ar}$ dating of the Bruhnes-Matuyama geomagnetic field reversal: Science, v. 256, p. 356-357

Brosgé, W.P., and Reiser, H.N., 1964, Geologic map and section of the Chandalar quadrangle, Alaska: U.S. Geological Survey Miscellaneous Geologic Investigations Map I-375, scale 1:250,000. 
Brosgé, W.P., Reiser, H.N., Dutro, J.T., Jr., and Detterman, R.L., 1979, Bedrock geologic map of the Philip Smith Mountains quadrangle, Alaska: U.S. Geological Survey Miscellaneous Field Investigations Map MF-879-B, scale $1: 250,000$.

Brown, Jerry, and Kreig, R.A., eds., 1983, Guidebook to permafrost and related features along the Elliott and Dalton Highways, Fox to Prudhoe Bay, Alaska: Fairbanks, Alaska Division of Geological \& Geophysical Surveys Guidebook 4, $230 \mathrm{p}$.

Brown, Jerry, Ferrians, O.J., Jr., Heginbottom, J.A., and Melnikov, E.S., 1997, Circum-Arctic map of permafrost and ground-ice conditions: U.S. Geological Survey CircumPacific Map Series CP-45, scale 1:10,000,000.

Brown, W.E., 2007, History of the central Brooks Range: Gaunt beauty, tenuous life: Fairbanks, University of Alaska Press, 219 p.

Burn, C.R., and Lewkowicz, A.G., 1990, Canadian landform examples-17: Retrogressive thaw slumps: Canadian Geographer, v. 34, p. 273-276.

Calkin, P.E., and Ellis, J.M., 1980, A lichenometric dating curve and its application to Holocene glacier studies in the central Brooks Range, Alaska: Arctic and Alpine Research, v. 12, p. 245-264.

Calkin, P.E., and Ellis, J.M., 1981, A cirque-glacier chronology based on emergent lichens and mosses: Journal of Glaciology, v. 27, p. 511-515.

Daanen, R.P., 2009, Debris slides or rock glaciers south side of Brooks Range, in Walker, D.A., Hamilton, T.D., Ping, C.L., Daanen, R.P., and Streever, W.W., Dalton Highway field trip guide for the Ninth International Conference on Permafrost: Fairbanks, Alaska Division of Geological \& Geophysical Surveys, Guidebook 9, p. 104.

Detterman, R.L., 1953, Sagavanirktok-Anaktuvuk region, northern Alaska, in Péwé, T.L., and others, Multiple glaciation in Alaska: U.S. Geological Survey Circular 289, p. 11-12.

Detterman, R.L., Bickel, R.S., and Gryc, George, 1963, Geology of the Chandler River region, Alaska: U.S. Geological Survey Professional Paper 303-E, p. E223-E324.

Detterman, R.L., Bowsher, A.L., and Dutro, J.T., Jr., 1958, Glaciation on the Arctic Slope of the Brooks Range, northern Alaska: Arctic, v. 11, p. 43-61.

Diel, W.R., and Banet, Arthur, Jr., 1993, Riches from the earth-A geologic tour along the Dalton Highway, Alaska: Anchorage, Alaska, Bureau of Land Management and Alaska Natural History Association, 128 p.

Dillon, J.T., Brosgé, W.P., and Dutro, J.T., Jr., 1986, Generalized geologic map of the Wiseman quadrangle, Alaska: U.S. Geological Survey Open-File Report OF 86-219, scale $1: 250,000$.

Ellis, J.M., 1978, Neoglaciation of the Atigun Pass area, eastcentral Brooks Range, Alaska: State University of New York at Buffalo, M.A. thesis, 113 p.

Ellis, J.M., 1982, Holocene glaciation of the central Brooks Range, Alaska: State University of New York at Buffalo, Ph.D. dissertation, $396 \mathrm{p}$.

Ellis, J.M., and Calkin, P.E., 1979, Nature and distribution of glaciers, neoglacial moraines, and rock glaciers, eastcentral Brooks Range, Alaska: Arctic and Alpine Research, v. 11, p. $403-420$.

Ellis, J.M., and Calkin, P.E., 1984, Chronology of Holocene glaciation, central Brooks Range, Alaska: Geological Society of America Bulletin, v. 95, p. 897-912.

Ellis, J.M., Calkin, P.E., and Bruen, M.P., 1984, Rock glaciers of the east central Brooks Range, Alaska (abs.), in Final Proceedings, 4th International Permafrost Conference, Fairbanks, Alaska, July 1983: Washington, D.C., National Academy Press, p. 322.

Ellis, J.M., Hamilton, T.D., and Calkin, P.E., 1981, Holocene glaciation of the Arrigetch Peaks, Brooks Range, Alaska: Arctic, v. 34, p. 158-168.

Ferrians, O.J., Jr., 1965, Permafrost map of Alaska: U.S. Geological Survey Miscellaneous Geologic Investigations Map I-445, scale 1:2,500,000.

Ferrians, O.J., Jr., 1971, Preliminary engineering geologic maps of the proposed Trans-Alaska Pipeline route: U.S. Geological Survey Open-File Report 492, 2 sheets, scale $1: 125,000$.

French, H.M., 2007, The periglacial environment (3rd ed.): Chichester, England, John Wiley \& Sons Ltd., 458 p.

Gedney, Larry, and Marshall, Dianne, 1981, A rare earthquake sequence in the Kobuk Trench, northwestern Alaska: Seismological Society of America Bulletin, v. 71, p. 1587-1592.

Grantz, Arthur, Dinter, D.A., and Biswas, N.N., 1983, Map, cross sections, and chart showing late Quaternary faults, folds, and earthquake epicenters on the Alaskan Beaufort shelf: U.S. Geological Survey Miscellaneous Investigations Map I-1182-C, 3 sheets, 7 p.

Hamilton, T.D., 1965, Comparative glacier photographs from northern Alaska: Journal of Glaciology, v. 5, p. 479-487.

Hamilton, T.D., 1969, Glacial geology of the lower Alatna Valley, Brooks Range, Alaska, in Schumm, S.A., and Bradley, W.C., eds., United States Contributions to Quaternary Research: Geological Society of America Special Paper 123, p. 181-223.

Hamilton, T.D., 1978a, Surficial geologic map of the Chandalar quadrangle, Alaska: U.S. Geological Survey Miscellaneous Field Studies Map MF-878-A, scale 1:250,000.

Hamilton, T.D., 1978b, Surficial geologic map of the Philip Smith Mountains quadrangle, Alaska: U.S. Geological Survey Miscellaneous Field Studies Map MF-879-A, scale $1: 250,000$.

Hamilton, T.D., 1978c, Late Cenozoic stratigraphy of the southcentral Brooks Range, p. B36-B38, in Johnson, K.M., ed., The United States Geological Survey in Alaska-Accomplishments during 1977: U.S. Geological Survey Circular 772-B, p. B36-B38.

Hamilton, T.D., 1979a, Quaternary stratigraphic sections with radiocarbon dates, Chandalar quadrangle, Alaska: U.S. Geological Survey Open-File Report 79-751, 10 p.

Hamilton, T.D., 1979b, Radiocarbon dates and Quaternary stratigraphic sections, Philip Smith Mountains quadrangle, Alaska: U.S. Geological Survey Open-File Report 79-866, $44 \mathrm{p}$. 
Hamilton, T.D., 1979c, Surficial geologic map of the Chandler Lake quadrangle, Alaska: U.S. Geological Survey Miscellaneous Field Studies Map MF-1121, scale 1:250,000.

Hamilton, T.D., 1979d, Surficial geologic map of the Wiseman quadrangle, Alaska: U.S. Geological Survey Miscellaneous Field Studies Map MF-1122, scale 1:250,000.

Hamilton, T.D., 1979e, Late Cenozoic glaciations and erosion intervals, north-central Brooks Range, in Johnson, K.M., and Williams, J.R., eds., The United States Geological Survey in Alaska-Accomplishments during 1978: U.S. Geological Survey Circular 804-B, p. B27-B29.

Hamilton, T.D., 1980a, Radiocarbon dates and Quaternary stratigraphic sections, Chandler Lake quadrangle, Alaska: U.S. Geological Survey Open-File Report 80-790, 28 p.

Hamilton, T.D., 1980b, Quaternary stratigraphic sections with radiocarbon dates, Wiseman quadrangle, Alaska: U.S. Geological Survey Open-File Report 80-791, 53 p..

Hamilton, T.D., 1980c, Surficial geologic map of the Killik River quadrangle, Alaska: U.S. Geological Survey Miscellaneous Field Studies Map MF-1234, scale 1:250,000.

Hamilton, T.D., 1981a, Surficial geologic map of the Survey Pass quadrangle, Alaska: U.S. Geological Survey Miscellaneous Field Studies Map MF-1320, scale 1:250,000.

Hamilton, T.D., 1981b, Episodic Holocene alluviation in the central Brooks Range - Chronology, correlations, and climatic implications, in Albert, N.R.D., and Hudson, Travis, eds., The United States Geological Survey in AlaskaAccomplishments during 1979: U.S. Geological Survey Circular 823-B, p. B21-B24.

Hamilton, T.D., 1982a, Quaternary stratigraphic sections with radiocarbon dates, Killik River quadrangle, Alaska: U.S. Geological Survey Open-File Report 82-606, 31 p.

Hamilton, T.D., 1982b, Relict Pleistocene glacier ice in northern Alaska, in Abstracts, Institute of Arctic and Alpine Research, 11th Annual Arctic Workshop, March 11-13, 1982: Boulder, Colo., University of Colorado, p. 25-26.

Hamilton, T.D., 1984a, Surficial geologic map of the Howard Pass quadrangle, Alaska: U.S. Geological Survey Miscellaneous Field Studies Map MF-1677, scale 1:250,000.

Hamilton, T.D., 1984b, Surficial geologic map of the Ambler River quadrangle, Alaska: U.S. Geological Survey Miscellaneous Field Studies Map MF-1678, scale 1:250,000.

Hamilton, T.D., 1984c, Late Quaternary offsets along the Kobuk and related fault zones, northwestern Alaska (abs.): Geological Society of America Abstracts with Programs, v. 16, p. 288.

Hamilton, T.D., 1986, Late Cenozoic glaciation of the central Brooks Range, in Hamilton, T.D., Reed, K.M., and Thorson, R.M., eds., Glaciation in Alaska-The geologic record: Anchorage, Alaska Geological Society, p. 9-49.

Hamilton, T.D., 1994, Late Cenozoic glaciation of Alaska, in Plafker, George, and Berg, H.C., eds., The Geology of Alaska: Boulder, Colo., The Geological Society of America, The Geology of North America, v. G-1, p. 813-844.

Hamilton, T.D., 2002a, Surficial geologic map of the Hughes quadrangle, Alaska: U.S. Geological Survey Miscellaneous Field Studies Map MF-2408, scale 1:250,000, 10 p.

Hamilton, T.D., 2002b, Surficial geologic map of the Bettles quadrangle, Alaska: U.S. Geological Survey Miscellaneous Field Studies Map MF-2409, scale 1:250,000, 9 p.

Hamilton, T.D., 2003, Surficial geology of the Dalton Highway (Itkillik-Sagavanirktok Rivers) area, southern Arctic Foothills, Alaska: Alaska Division of Geological \& Geophysical Surveys Professional Report 121, scale 1:63,360, 32 p.

Hamilton, T.D., 2009, Guide to surficial geology and river-bluff exposures, Noatak National Preserve, northwestern Alaska: U.S. Geological Survey Scientific Investigations Report 2008-5125, 116 p.

Hamilton, T.D., and Brubaker, L.B., 1983, Quaternary stratigraphic sections with radiocarbon dates, Survey Pass quadrangle, Alaska: U.S. Geological Survey Open-File Report 83-72, $47 \mathrm{p}$.

Hamilton, T.D., Lancaster, G.A., and Trimble, D.A., 1987, Glacial advance of late Wisconsin (Itkillik II) age in the upper Noatak River valley-A radiocarbon-dated stratigraphic record, in Hamilton, T.D., and Galloway, J.P., eds., Geologic studies in Alaska by the U.S. Geological Survey during 1986: U.S. Geological Survey Circular 998, p. 35-39.

Hamilton, T.D., and Obi, C.M., 1982, Pingos in the Brooks Range, northern Alaska: Arctic and Alpine Research, v. 14, p. 13-20.

Hamilton, T.D., and Porter, S.C., 1975, Itkillik glaciation in the Brooks Range, northern Alaska: Quaternary Research, v. 5, p. 471-497.

Hampel, Andrea, Hetzel, Ralf, and Densmore, A.L., 2007, Postglacial slip-rate increase on the Teton normal fault, northern Basin and Range Province, caused by melting of the Yellowstone ice cap and deglaciation of the Teton Range?: Geology, v. 35, p. 1107-1110.

Hopkins, D.M., 1975, Time-stratigraphic nomenclature for the Holocene epoch: Geology, v. 3, p. 10.

Kachadoorian, Reuben, 1971, Preliminary engineering geologic maps of the proposed trans-Alaska pipeline route-Wiseman and Chandalar quadrangles: U.S. Geological Survey Open File Report 486, 2 sheets, scale 1:125,000.

Keller, Katy, Blum, J.D., and Kling, G.W., 2007, Geochemistry of soils and streams on surfaces of varying ages in arctic Alaska: Arctic, Antarctic, and Alpine Research, v. 39, p. 84-98.

Kelley, J.S., 1990, Generalized geologic map of the Chandler Lake quadrangle, north-central Alaska: U.S. Geological Survey Miscellaneous Field Studies Map MF-2144-A, scale $1: 250,000,19 \mathrm{p}$.

Keroher, G.C., and others, 1966, Lexicon of geologic names of the United States for 1936-1960: U.S. Geological Survey Bulletin 1200, $4341 \mathrm{p}$.

Kurtak, J.M., Klieforth, R.F., Clark, J.M., and Maclean, E.A., 2002, Mineral investigations in the Koyukuk Mining District, northern Alaska: U.S. Dept. Interior Bureau of Land Management, BLM-Alaska Tech. Report 50, 2 vol., 65 p., 11 Appendices (paged separately).

Luckman, B.H., 1978, Geomorphic work of snow avalanches in the Canadian Rocky Mountains: Arctic and Alpine Research, v. 10, p. 261-276. 
Mascarelli, A.L., 2009, Quaternary geologists win timescale vote: Nature (Nature News), v. 459, p. 624.

Mayfield C.F., and Tailleur, I.L., 1978, Bedrock geologic map of the Ambler River quadrangle, Alaska: U.S. Geological Survey Open-File Report 78-120A, scale 1:250,000.

Moore, T.E., Nilsen, T.H., and Brosgé, W.P., 1989, Sedimentology of the Kanayut Conglomerate, in Mull, C.G., and Adams, K.E., eds., Dalton Highway, Yukon River to Prudhoe Bay, Alaska: Fairbanks, Alaska Division of Geological \& Geophysical Surveys Guidebook 7, v. 2, p. 219-252.

Moore, T.E., Wallace, W.K., Bird, K.J., Karl, S.M., Mull, C.G., and Dillon, J.T., 1994, Geology of northern Alaska, in Plafker, George, and Berg, H.C., eds., The Geology of Alaska: the Geological Society of America, The Geology of North America, v. G-1, p. 49-140.

Mull, C.G., Moore, T.E., Harris, E.E., and Tailleur, I.L., 1994, Geologic map of the Killik River quadrangle, Brooks Range, Alaska: U.S. Geological Survey Open-File Report 94-679, scale 1:250,000.

Munroe, J.S., and Bockheim, J.G., 2001, Soil development in low-arctic tundra of the northern Brooks Range, Alaska, U.S.A.: Arctic, Antarctic, and Alpine Research, v. 33, p. 78-87.

Nelson, S.W., and Grybeck, Donald, 1980, Geologic map of the Survey Pass quadrangle, Alaska: U.S. Geological Survey Miscellaneous Field Studies Map MF-1176-A, scale $1: 250,000$.

Nilsen, T.H., and Moore, T.E., 1984, Stratigraphic nomenclature for the Upper Devonian and Lower Mississippian(?) Kanayut Conglomerate, Brooks Range, Alaska: U.S. Geological Survey Bulletin 1529-A, p. A1-A64.

Onesti, L.J., 1983, Slushflow activity in the Atigun Pass area, in Brown, Jerry, and Kreig, R.A., eds., Guidebook to permafrost and related features along the Elliott and Dalton Highways, Fox to Prudhoe Bay, Alaska: Fairbanks, Alaska Division of Geological \& Geophysical Surveys Guidebook 4, p. 159-162.

Onesti, L.J., 1989, Depositional environment and morphology of slush avalanche deposits, central Brooks Range, Alaska (abs.): Geological Society of America Abstracts with Programs, v. 21, no. 6, p. A59.

Onesti, L.J., and Walti, S.A., 1983, Hydrologic characteristics of small arctic-alpine watersheds, central Brooks Range, Alaska, in Permafrost International Conference Proceedings, 4th, Fairbanks, Alaska, July 1983: Washington, D.C., National Academy Press, p. 957-961.

Patton, W.W., Jr., and Miller, T.P., 1966, Regional geologic map of the Hughes quadrangle, Alaska: U.S. Geological Survey Miscellaneous Geologic Investigations Map I-459, scale $1: 250,000$.

Patton, W.W., Jr., Miller, T.P., and Tailleur, I.L., 1968, Regional geologic map of the Shungnak and southern part of the Ambler River quadrangles, Alaska: U.S. Geological Survey Miscellaneous Geologic Investigations Map I-554, scale 1:250,000.

Patton, W.W., Jr., and Miller, T.P., 1973, Bedrock geologic map of Bettles and southern part of Wiseman quadrangles, Alaska: U.S. Geological Survey Miscellaneous Field Stud- ies Map MF-492, scale 1:250,000.

Patton, W.W., Jr., Box, S.E., Moll-Stalcup, E.J., and Miller, T.P., 1994, Geology of west-central Alaska, in Plafker, George, and Berg, H.C., eds., The geology of Alaska: Geological Society of America, The Geology of North America, v. G-1, p. 241-269.

Pelletier, J.D., 2004, Estimate of three-dimensional flexuralisostatic response to unloading: Rock-uplift due to late Cenozoic glacial erosion in the western United States: Geology, v. 32, p. 161-164.

Porter, S.C., 1964, Late Pleistocene glacial chronology of north-central Brooks Range, Alaska: American Journal of Science, v. 262, p. 446-460.

Porter, S.C., 1966, Pleistocene geology of Anaktuvuk Pass, central Brooks Range, Alaska: Arctic Institute of North America Technical Paper 18, 100 p.

Porter, S.C., and Denton, G.H., 1967, Chronology of Neoglaciation in the North American Cordillera: American Journal of Science, v. 265, p. 177-210.

Richmond, G.M., and Fullerton, D.S., 1986, Introduction, in Richmond, G.M., and Fullerton, D.S., eds., Quaternary Glaciations in the United States of America: Quaternary Science Reviews, v. 5 (Quaternary Glaciations in the Northern Hemisphere), p. 3-10.

Shulski, Martha, and Wendler, Gerd, 2007, The Climate of Alaska: Fairbanks, University of Alaska Press, 216 p.

Sloan, C.E., Zenone, Chester, and Mayo, L.R., 1976, Icings along the Trans-Alaska Pipeline route: U.S. Geological Survey Professional Paper 979, 31p.

Smith, P.S., and Mertie, J.B., Jr., 1930, Geology and mineral resources of northwestern Alaska: U.S. Geological Survey Bulletin 815, $351 \mathrm{p}$.

Till, A.B., Dumoulin, J.A., Harris, A.G., Moore, T.E., Bleick, H.A., and Siwiec, B.R., 2008, Bedrock geologic map of the southern Brooks Range, Alaska, and accompanying conodont data: U.S. Geological Survey Open-File Report 2008-1149, 2 sheets, scales 1:500,000 and 1:600,000, 88 p. [http://pubs.usgs.gov/of/2008/1149]

Wahrhaftig, Clyde, 1965, Physiographic divisions of Alaska: U.S. Geological Survey Professional Paper 482, 52 p.

Walker, D.A., Hamilton, T.D., Ping, C.L., Daanen, R.P., and Streever, W.W., 2009, Dalton Highway field trip guide for the Ninth International Conference on Permafrost: Fairbanks, Alaska Division of Geological \& Geophysical Surveys Guidebook 9, 104 p.

Washburn, A.L., 1980, Geocryology-A survey of periglacial processes and environments: New York, John Wiley, 406 p.

White, S.E., 1976, Rock glaciers and block fields, review and new data: Quaternary Research, v. 6, p. 77-97.

Williams, J.R., 1970, Ground water in the permafrost regions of Alaska: U.S. Geological Survey Professional Paper 696, $83 \mathrm{p}$.

Yeend, W.E., 1972, Winter protalus mounds: Brooks Range, Alaska: Arctic and Alpine Research, v. 4, p. 85-88.

Yoshikawa, K., Hinzman, L.D., and Kane, D.L., 2007, Spring and aufeis (icing) hydrology in Brooks Range, Alaska: Journal of Geophysical Research, v. 112 , G04S43, doi: 10.1029/2006JG000294. 